\section{Creutzfeldt-Jakob disease and the eye. I. Background and patient management}

\section{C.J. LUECK, G.G. MCILWAINE, M. ZEIDLER}

\section{Background}

The transmissible spongiform encephalopathies (TSEs), alternatively known as prion diseases, excite a fascination among both medical personnel and lay public for several reasons. They are the only known example of diseases which can be transmitted both genetically and by infection, though in most human examples the exact aetiology remains unknown. The nature of the infective agent is still not completely clear, the diseases are uniformly (and usually rapidly) fatal, and there is no known cure. Consequently, it is not surprising that there has been an enormous amount published on the subject. Indeed, if the number of publications on any disease is divided by the incidence of that disease, human TSEs reveal an 'interest factor' over 10 times that of any other condition, and over 100 times that of most. ${ }^{1}$ This is reflected in the size of the reference lists at the end of this article and its companion! ${ }^{2}$

The history of TSEs has involved the eye in a variety of ways. The first evidence that scrapie could be transmitted experimentally followed inoculation through the eye ${ }^{3}$ and the first evidence that Creutzfeldt-Jakob disease (CJD) could be transmitted directly from human to human by infection involved a corneal graft. ${ }^{4}$ Visual symptoms are frequent, as are neuroophthalmological signs, and it is therefore likely that some patients will present to an ophthalmologist. This review and the companion article ${ }^{2}$ set out to provide the reader with an update on the current understanding of human TSEs, and to discuss the management of patients, with particular reference to corneal transplantation. As yet, there is no effective treatment, ${ }^{5}$ so this aspect will not be discussed further. In the companion article ${ }^{2}$ we review the ophthalmic and neuro-ophthalmic features of these diseases in greater depth.

\section{Methods \\ In preparing this review, MEDLINE and EMBASE were consulted using the following combination of keywords: CJD, Creutzfeld, Creutzfeldt, Creutzfeldt-Jakob disease, Creutzfeldt-Jakob syndrome, eye, fatal familial}

insomnia, FFI, Gerstmann-Sträussler-Scheinker, Gerstmann-Sträussler-Scheinker disease, GSS, Heidenhain, Jacob, Jakob, kuru, ocular, ophthalmic, ophthalmological, optic, prion, prion disease, $\operatorname{PrP}$, PrPSc, transmissible spongiform encephalopathy, TSE, vision, visual, in addition to various permutations of accommodation, evoked potentials, eye and eye diseases, ocular motility disorders, and vision. Major neurological, ophthalmological and neuro-ophthalmological journals were also screened by hand over the last 10 years.

Secondary referencing was carried out from the papers found by these procedures.

\section{Transmissible spongiform encephalopathies}

There are several different TSEs affecting animals and man, and a summary is given in Table 1. This article will deal with those diseases affecting man, i.e. CJD, Gerstmann-SträusslerScheinker disease (GSS), fatal familial insomnia (FFI) and kuru.

Neuropathologically, these conditions are recognised by the triad of spongiform change (affecting any part of the cerebral grey matter), neuronal loss, and proliferation and hypertrophy of astrocytes. ${ }^{6-8}$ Neurons show loss of dendritic spines and intracytoplasmic vacuoles, ${ }^{9}$ and there is accumulation in the brain of amyloid. The amyloid consists of an abnormal, 33-37 kDa degradation-resistant glycoprotein, ${ }^{10}$ which is an isoform of a normally occurring protein known variously as prion protein (PrP), scrapie-associated protein, proteinase resistant protein, scrapie amyloid protein, or Sp33-37. ${ }^{11,12}$ The normal, or wildtype, is known as $\operatorname{PrP}^{\mathrm{C}}$ ('cellular', principally $\alpha$ helical structure, detergent soluble) and the abnormal isoform as $\mathrm{PrP}^{\mathrm{Sc}}$ ('Scrapie', principally $\beta$-sheet structure, insoluble in non-denaturing detergents). ${ }^{13}$

$\operatorname{PrP}^{C}$ is a normal constituent of the neuronal cell membrane, ${ }^{14,15}$ but it is also widely expressed throughout the body. ${ }^{12}$ It is transported along neurons ${ }^{16}$ and accumulates at the neuromuscular junction. ${ }^{17}$ Scrapie infection has been shown to alter receptor-mediated $\mathrm{Ca}^{2+}, 18$ and other reports suggest that $\operatorname{PrP}^{\mathrm{C}}$ may be necessary for neuronal transmission ${ }^{19,20}$ or
C. Lueck

G.G. Mcllwaine

M. Zeidler

Department of Clinical

Neuroscience

Western General Hospital

Edinburgh, UK

\section{G.G. Mcllwaine}

Princess Alexandra Eye

Pavilion

Edinburgh, UK

M. Zeidler

National CJD Surveillance Unit

Western General Hospital Edinburgh, UK

\section{$\operatorname{Dr}$ C.J. Lueck}

Department of Clinical Neuroscience

Western General Hospital

Crewe Road

Edinburgh EH4 2XU

Scotland, UK

Tel: +44 (0)1315372452

Fax: +44 (0)1315371030

e-mail: c|@skull.den.ed.ac.uk

Received: 20 August 1999 Accepted in revised form: 9 December 1999 
Table 1. Documented non-experimental animal TSES

\begin{tabular}{|c|c|}
\hline Transmissible spongiform encephalopathy & $\begin{array}{c}\text { First } \\
\text { reported }\end{array}$ \\
\hline \multicolumn{2}{|l|}{ Human TSE } \\
\hline \multicolumn{2}{|l|}{ Creutzfeldt-Jakob disease } \\
\hline Classical sporadic & 1920 \\
\hline Familial & 1924 \\
\hline Iatrogenic & 1974 \\
\hline New variant & 1996 \\
\hline Gerstmann-Sträussler-Scheinker disease & 1936 \\
\hline Fatal familial insomnia & 1986 \\
\hline Kuru & 1957 \\
\hline \multicolumn{2}{|l|}{ Animal TSE } \\
\hline \multicolumn{2}{|l|}{ Scrapie in: } \\
\hline Sheep & 1730 \\
\hline Goat & 1942 \\
\hline Moufflon & 1992 \\
\hline Transmissible mink encephalopathy & 1965 \\
\hline Chronic wasting disease of deer and elk & 1967 \\
\hline Bovine spongiform encephalopathy & 1986 \\
\hline Captive primates & 1999 \\
\hline \multicolumn{2}{|l|}{ Spongiform encephalopathy in captive Felidae: } \\
\hline Domestic cat & 1990 \\
\hline Puma & 1992 \\
\hline Cheetah & 1992 \\
\hline Ocelot & 1994 \\
\hline Tiger & 1996 \\
\hline \multicolumn{2}{|l|}{ Captive ruminants: } \\
\hline Nyala & 1986 \\
\hline Gemsbok & 1988 \\
\hline Arabian oryx & 1989 \\
\hline Eland & 1989 \\
\hline Greater kudu & 1989 \\
\hline Scimitar-horned oryx & 1993 \\
\hline Ankole & 1995 \\
\hline Bison & 1996 \\
\hline
\end{tabular}

that it may influence the activity of $\mathrm{Cu} / \mathrm{Zn}$ superoxide dismutase, ${ }^{21}$ but little else is known about its normal function. The fact that it is possible to rear transgenic mice totally devoid of the protein ${ }^{22}$ implies that it is not essential for life, and adds to the confusion.

\section{Pathogenesis}

The transmissible nature of sporadic CJD was first demonstrated experimentally in $1968,{ }^{23}$ and it has subsequently been shown that it is possible to transmit familial CJD, ${ }^{24,25} \mathrm{GSS}^{26}$ and other forms of familial prion disease to animals. However, the precise nature of the transmissible agent is still not clear. Three main hypotheses have been put forward. ${ }^{11}$ One suggests that the infective agent is comprised of proteins surrounding a nucleic acid which encodes those proteins (i.e. a virus), ${ }^{27}$ the second that it comprises proteins associated with a small polynucleotide (the 'virino' hypothesis ${ }^{28}$ ), and the third that it is entirely composed of protein and devoid of nucleic acid, ${ }^{29}$ subsequently termed a prion ('proteinaceous particle'). ${ }^{30}$ It is now clear that the altered protein, $\mathrm{PrP}^{\mathrm{Sc}}$, is a major and necessary component of the infectious agent, ${ }^{10,31,32}$ but exactly how it is pathogenic remains uncertain.
The most compelling hypothesis to date is the third, the 'protein-only' hypothesis, which involves conformational change of $\operatorname{PrP} .^{13,29,33-35}$ It has been shown that $\operatorname{PrP}^{\mathrm{C}}$ and $\operatorname{PrP}^{\mathrm{Sc}}$ are stereoisomers (or 'twisted' forms) of the same protein. ${ }^{36}$ The former occurs normally, but can be caused to 'flip' into an altered shape, $\mathrm{PrP}^{\mathrm{Sc}}$. Once this has happened, the protein becomes resistant to proteases and so can build up in the cell membrane, eventually aggregating as amyloid. The reason $\operatorname{PrP}^{\mathrm{Sc}}$ is pathogenic is not known, but recent work has suggested that small segments of some genetically abnormal PrP molecules may display a tendency to aggregate, and be pathogenic in cell culture. ${ }^{37,38}$ Consistent with the suggestion that it is indeed the $\mathrm{PrP}^{\mathrm{Sc}}$ itself which is pathogenic is the fact that those areas of the brain demonstrating the most marked spongiform change have the highest concentration of $\mathrm{PrP}^{\mathrm{Sc} 15}$. Furthermore, transgenic mice reared without the PrP gene cannot be infected with scrapie, demonstrating that $\operatorname{PrP}$ is necessary for the disease. ${ }^{39}$

The suggestion is that the normal, or wild-type, $\operatorname{PrP}^{C}$ is converted into $\mathrm{PrP}^{\mathrm{Sc}}$ by coming into direct contact with $\mathrm{PrP}^{\mathrm{Sc}}$, and that, once this starts, a cascading chainreaction commences affecting $\operatorname{Prp}^{C}$ all over the brain. Thus, the normal brain is in a sort of 'metastable equilibrium', stable unless $\mathrm{PrP}^{\mathrm{Sc}}$ is introduced, in which case normal $\mathrm{PrP}^{\mathrm{C}}$ is gradually caused to 'flip' into the abnormal form (Fig. 1). An analogy might be that of crystals developing out of a supersaturated salt solution once it has been 'seeded' by a small salt crystal. ${ }^{40}$ The abnormal $\mathrm{PrP}^{\mathrm{Sc}}$ could be introduced by way of direct inoculation, as in transmitted CJD, or develop spontaneously if the normal host $\mathrm{PrP}$ is more unstable than usual due to genetic defects, or develop as a rare stochastic event in the sporadic form of the disease. Quite how the abnormal PrP is transmitted from cell to cell is not clear.

While the above hypothesis is compelling, it does not explain all aspects of TSE transmission, most notably the existence of different 'strains' of the diseases. These are discussed further below. Detailed reviews of the prion concept can be found elsewhere. ${ }^{22,31-33,36,41-45}$

\section{Creutzfeldt-Jakob Disease}

Creutzfeldt ${ }^{46}$ and Jakob ${ }^{47-49}$ are usually credited with having described the condition first, ${ }^{50}$ though Fischer ${ }^{51}$ described cases of spongiform cortical degeneration some 10 years earlier (none of which would meet the modern criteria for CJD). Interestingly, the original case described by Creutzfeldt probably did not have CJD on the basis of histology, 52 and, of Jakob's five patients, only the third and fifth definitely did. ${ }^{52}$ The early literature (well reviewed by May $^{53}$ and Kirschbaum ${ }^{54}$ ) was similarly confused by the lack of standard criteria and a plethora of synonyms, ${ }^{55}$ and it was not until full evaluation of the neuropathological changes in the brain were made in $1978,{ }^{6}$ and criteria generally agreed upon, ${ }^{56}$ 


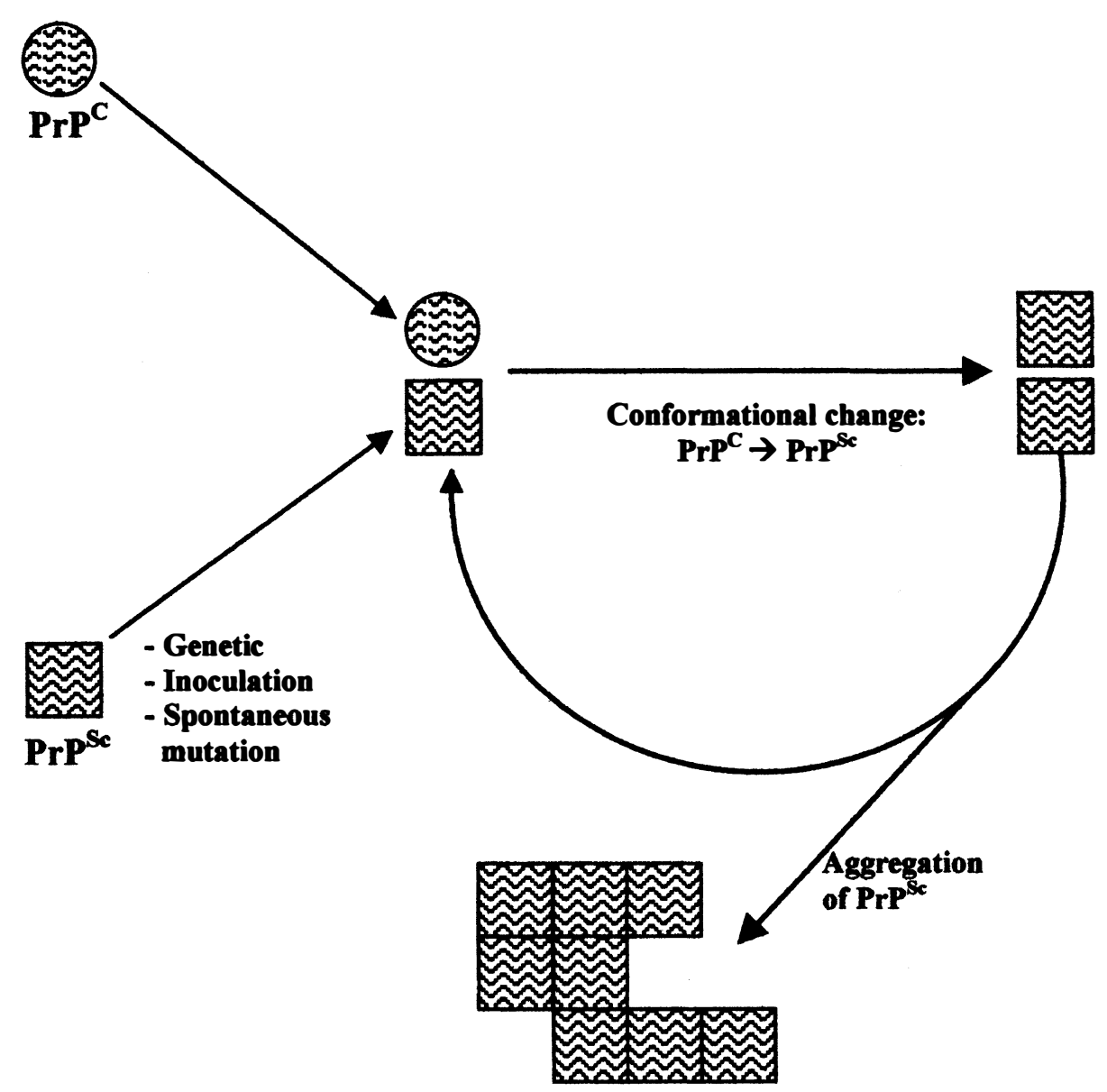

Amyloid

Fig. 1. Pathogenesis. The presence of abnormal $\operatorname{PrP}^{S c}$ somehow induces a conformational change in normal $\operatorname{Pr} P^{C}$, thereby converting it to PrP ${ }^{S c}$. $\operatorname{Pr} P^{S c}$ thus formed can convert more $\operatorname{Pr} P^{C}$ into $\operatorname{Pr} P^{S c}$ or aggregate to form insoluble amyloid.

that the picture began to become clearer. In particular, it was accepted that the 'gold standard' for diagnosis was histology (either brain biopsy or autopsy)..$^{56,57}$

CJD occurs throughout the world with an overall incidence of approximately $0.5-1.5$ per million population per year as evidenced by epidemiological studies in Europe, ${ }^{58-71}$ the USA, ${ }^{56,72-74}$ Israel, $^{75}$ South America ${ }^{76}$ and Japan. ${ }^{77,78}$ Almost all these studies demonstrate an increased incidence in urban centres compared with the rural incidence, but this may be an artefact of case ascertainment. There are also a few areas of high incidence, such as among Libyan-born Israelis (40 per million per year), ${ }^{79-81}$ due to genetic factors (see below).

The sex incidence is probably equal, $52,53,60,61,71,76$ though some studies have found a slight male preponderance ${ }^{56,59}$ and others the reverse. ${ }^{58,64-66,70,74,78,82}$ For a sporadic CJD, the mean age of onset is in the range 55-65 years, ${ }^{26,59-61,64,66,70,73,76,82}$ but it has occurred in a patient aged 92 years $^{83}$ and in one as young as 14 years. ${ }^{84}$ The median and mean duration of illness are approximately 4 and 8 months, respectively, $60,64,65,73,76,83$ but occasionally patients survive for much longer.

The disease typically evolves as a dementing illness with associated ataxia, myoclonus, and a wide variety of other neurological abnormalities. ${ }^{11,85}$ World Health Organization (WHO) clinical criteria ${ }^{86}$ are given in Table 2 .

Several different clinical types have been delineated, of which the classic, or 'frontopyramidal' type, constitutes the triad of a rapidly progressive dementia with myoclonus and characteristic electrocephalogram (EEG) changes. ${ }^{54,87}$ Of these, some $40 \%$ present with cognitive dysfunction alone, $30 \%$ with cerebellar dysfunction alone, and $10 \%$ with both. ${ }^{88}$ An 'amaurotic' form (or 'Heidenhain variant ${ }^{89-91}$ ) in which the initial symptoms are predominantly visual occurs in about $10 \% .{ }^{88}$ Rarer variants include a 'panencephalopathic' type showing major additional involvement of the white matter and occurring most frequently, but not universally, in Japan, ${ }^{92-101}$ and an 'ataxic' form in which the initial symptoms are predominantly cerebellar. ${ }^{102-105}$ More recently, a '(new) variant' has been described, ${ }^{106,107}$ probably related to bovine spongiform encephalopathy (BSE). This is dealt with in detail below. More unusual phenotypes include a more slowly progressive illness ${ }^{108,109}$ and presentation with a stroke-like onset. ${ }^{110}$ Other cases have been reported with lower motor neuron 
Table 2. Revised WHO definition of CJD subtypes ${ }^{86}$

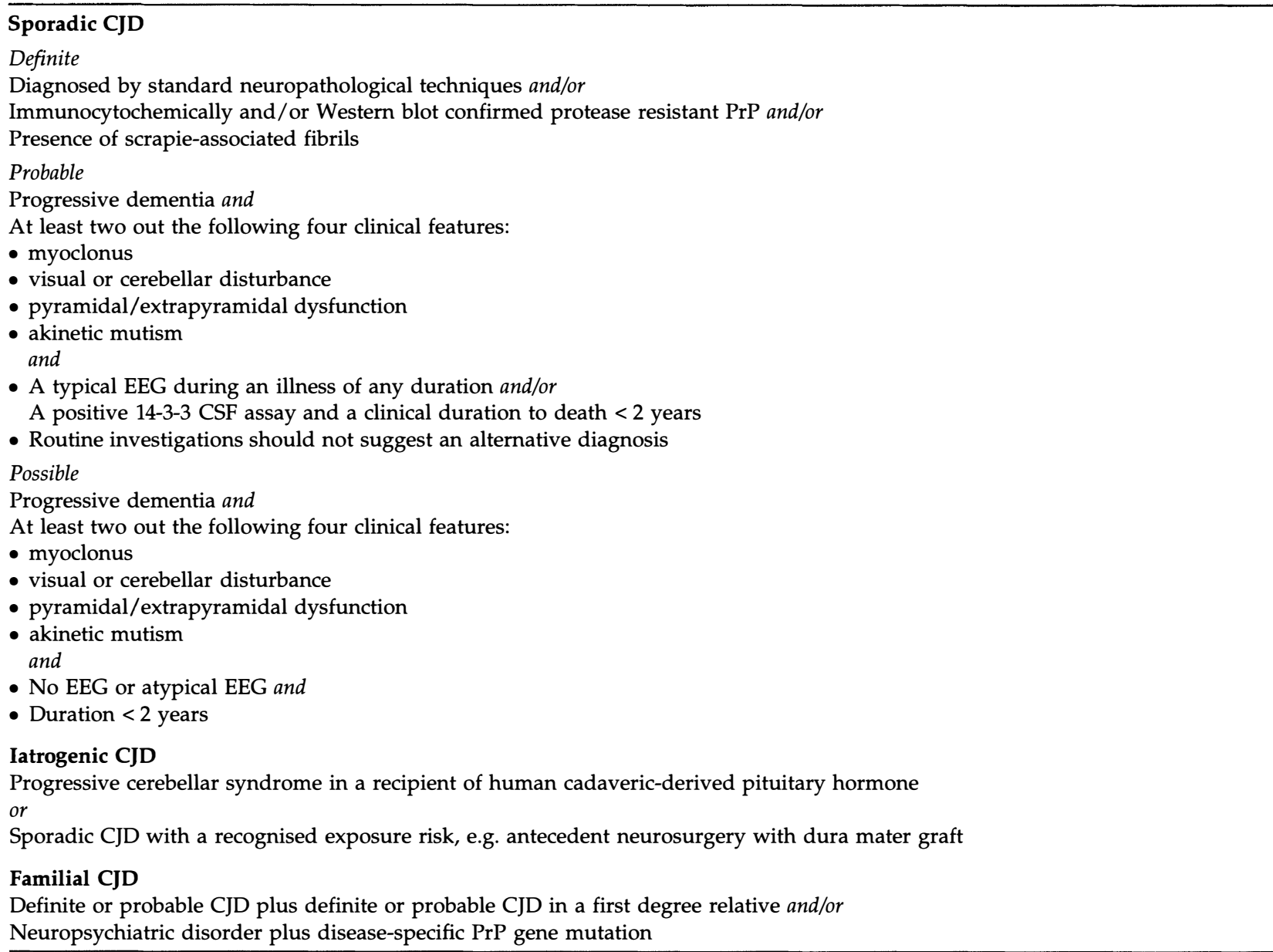

involvement (these were probably frontal lobe dementia with motor neurone disease) ${ }^{108,111}$ or a peripheral neuropathy (the significance of which is far from clear), ${ }^{112,113}$ but these will not be dealt with further.

It should be noted that, while histology is the gold standard for diagnosis, genetic studies have now revealed that cases of dementia may occur due to genetic abnormalities of the PrP gene but without the characteristic spongiform changes. ${ }^{114}$ This raises the possibility of under-ascertainment. ${ }^{114}$

\section{Variant CJD (vCJD)}

Most patients with sporadic CJD are in the 55-75 year age range. Previous reports of sporadic cases occurring in patients under 30 years are rare. ${ }^{77,84,85,115-120}$ In 1995, two cases of young-onset CJD were reported in the UK in persons aged 18 and 16 years. ${ }^{121,122}$ It subsequently became clear that these were the first of a series of cases with clearly different neuropathological features (in particular, 'florid plaques'), ${ }^{106,123}$ and 'new variant' CJD was described in $1996 .{ }^{106}$ The term 'new variant' has since been abandoned in favour of 'variant'. Compared with sporadic CJD, these patients have a much younger age of onset (mean 29, range 16-50 years) and a relatively distinct clinical course with early behavioural changes, ${ }^{124}$ or sensory disturbance (or both), and a more prolonged duration of illness. In some, choreoathetosis or dystonia is a feature, and myoclonus develops late. ${ }^{107,125,126}$ None of the cases reported had typical periodic EEG changes. ${ }^{106,125}$ Imaging was reported to be normal in most cases, ${ }^{107,125}$ though subsequent detailed analysis has suggested that signal change in the pulvinar on magnetic resonance imaging (MRI) is a frequent finding. ${ }^{127,128}$ It is of interest that the pathological changes are particularly pronounced in the occiptal lobes. $^{123}$

BSE was first described in $1987^{129}$ and has occurred vastly more frequently in the UK than elsewhere. ${ }^{130}$ Current evidence suggests that the disease originated from the use of animal feed supplements containing meat and bonemeal (MBM) contaminated by a TSE agent. The stringency of the rendering procedure by which animal materials were processed to produce MBM changed during the 1970s and 1980s. Decreased use of hydrocarbon solvents and the adoption of lower temperatures probably resulted in increased survival of the infective agent. Epidemiological evidence suggests that sheep scrapie, endemic in Great Britain, was the likely source of the infective agent contaminating the MBM which initiated the BSE epidemic. However, a further hypothesis is that BSE may have been an 
uncommon sporadic and/or hereditary disease of cattle which was dramatically amplified as a result of infected bovine material entering the modified rendering process. Whatever the origin of the agent responsible for BSE, it is clear that the recycling of infected cattle through the rendering process in the 1980s was responsible for fuelling the large and explosive epidemic. ${ }^{131}$

The peak incidence of BSE was in 1992-3, and the subsequent decline was largely due to a governmental ban on the feeding of ruminant-derived protein to cattle. ${ }^{132}$ Granted that there had recently been an epidemic of BSE in Britain, much speculation arose as to whether this could be transmitted to humans in the form of CJD. An increased incidence of CJD among British farm workers was reported in the early to mid1990s, ${ }^{133-136}$ and most of these had worked on farms with cases of BSE. This led to much concern that BSE was the cause of occupationally acquired CJD in these farmers. ${ }^{137}$ However, these cases did not exhibit an unusual clinicopathological phenotype, and a similarly high incidence of CJD in farm workers was seen in other countries without BSE. ${ }^{68,69,130}$ This suggested that there was an increased incidence of CJD in farm workers for reasons unrelated to BSE or, more likely, ascertainment bias arising through more vigorous investigation of farmers because of the concern over a possible connection. Subsequent strain-typing studies have failed to identify the BSE strain type as the cause of any of the British cases of CJD in farm workers. ${ }^{138,139}$

At the time of publishing (June 2000) a total of 67 cases of $\mathrm{vCJD}$ have been identified in the UK along with a single case in France and one in Ireland. In contrast to the cases of CJD in British farm workers, there is now strong evidence that VCJD is causally related to BSE: first, the temporo-spatial association; ${ }^{140}$ second,

neuropathological features similar to those of vCJD are seen in macaque monkeys inoculated intracerebrally with BSE, ${ }^{141}$ and, third, the 'strain' of the vCJD agent (see below) is identical to that of the BSE agent, but different from conventional CJD agents. ${ }^{139,142-144}$

Interestingly, all patients with vCJD have been homozygous for methionine (met/met) at codon $129,106,121,122$ a naturally occurring polymorphism in the human PrP gene (see below). Cattle do not show this polymorphism, all animals being met/met; humans with the met/met genotype may thus have increased susceptibility to BSE. ${ }^{145}$ This is discussed further below.

The incubation period remains unknown, with estimates for the average period ranging from 10 to 30 years. The route of infection is also unknown, but epidemiological studies provide no evidence for parenteral inoculation and the most likely route is presumed to be oral. ${ }^{146}$ The future number of cases is impossible to predict accurately. ${ }^{147-150}$ There has been a recent increase in incidence of deaths due to vCJD, but the significance of this is unclear. ${ }^{151,152}$

\section{Gerstmann-Sträussler-Scheinker (GSS) disease}

$\mathrm{GSS}^{153}$ is a very rare (1-10 cases per 100 million persons per year ${ }^{154}$ ) hereditary form of progressive ataxia associated with several different mutations of the PrP gene (see below). It is effectively a variant of familial CJD with a clinical course which may extend up to 5 or more years. The clinical phenotype can vary considerably in a single kindred and range from a picture indistinguishable from sporadic CJD with a rapidly progressive myoclonic dementia and typical periodic EEG to a slowly progressive spinocerebellar ataxia. ${ }^{26,155}$ Pathologically, multicentric amyloid ('kuru') plaques are the hallmark of GSS. ${ }^{156}$

Three forms have been distinguished: the typical ataxic form, a telencephalic form (dementia, parkinsonism and pyramidal features) ${ }^{157-159}$ and a variant with numerous neurofibrillary tangles pathologically. ${ }^{160,161}$

\section{Fatal familial insomnia (FFI)}

First described in $1986,{ }^{162}$ FFI is a rapidly progressive, autosomal dominantly inherited disease presenting in adult life (ages 40-60 years) and associated with a mutation at codon 178 of the PrP gene (and methionine 'downstream' on the same allele at codon 129 - if valine is present at codon 129 on the same allele, then the phenotype is similar to sporadic CJD) ${ }^{162-168}$ (see below). It is characterised clinically by untreatable insomnia, endocrine disturbance, dysautonomia (hyperhidrosis, hyperthermia, tachycardia, hypertension and irregular breathing) and motor abnormalities (ataxia, myoclonus and pyramidal dysfunction). The pathological features include selective atrophy of the anterior ventral and mediodorsal thalamic nuclei with other changes such as cortical gliosis, cerebellar and inferior olivary atrophy. Interestingly, spongiform degeneration is not always present. ${ }^{164}$ To date, only 24 kindreds have been described. ${ }^{169}$

To confuse matters, there are reported cases of codon 200 related CJD resulting in the clinical phenotype of $\mathrm{FFI}^{170}$ and, more recently, a sporadic form of CJD clinically identical to FFI but not associated with the genetic mutation of the PrP gene has been described ('sporadic fatal insomnia' (SFI)). ${ }^{171}$ Furthermore, most of the cases in Germany with the FFI mutation did not have insomnia, ${ }^{172}$ and only about $50 \%$ of FFI cases have a family history of the disease!

\section{Kuru}

Kuru was initially described in $1957 .{ }^{173}$ It is characterised by cerebellar ataxia and a shivering-like tremor ( $k u r u$ ), progressing to complete motor incapacity and death in less than 1 year from onset. It is almost entirely confined to the Fore-speaking tribes in Papua New Guinea, affects all ages, but is rare in adult males, and is thought to have been transmitted by ritual cannibalism. ${ }^{174}$ With the cessation of this practice, it has largely died out. ${ }^{175}$ 


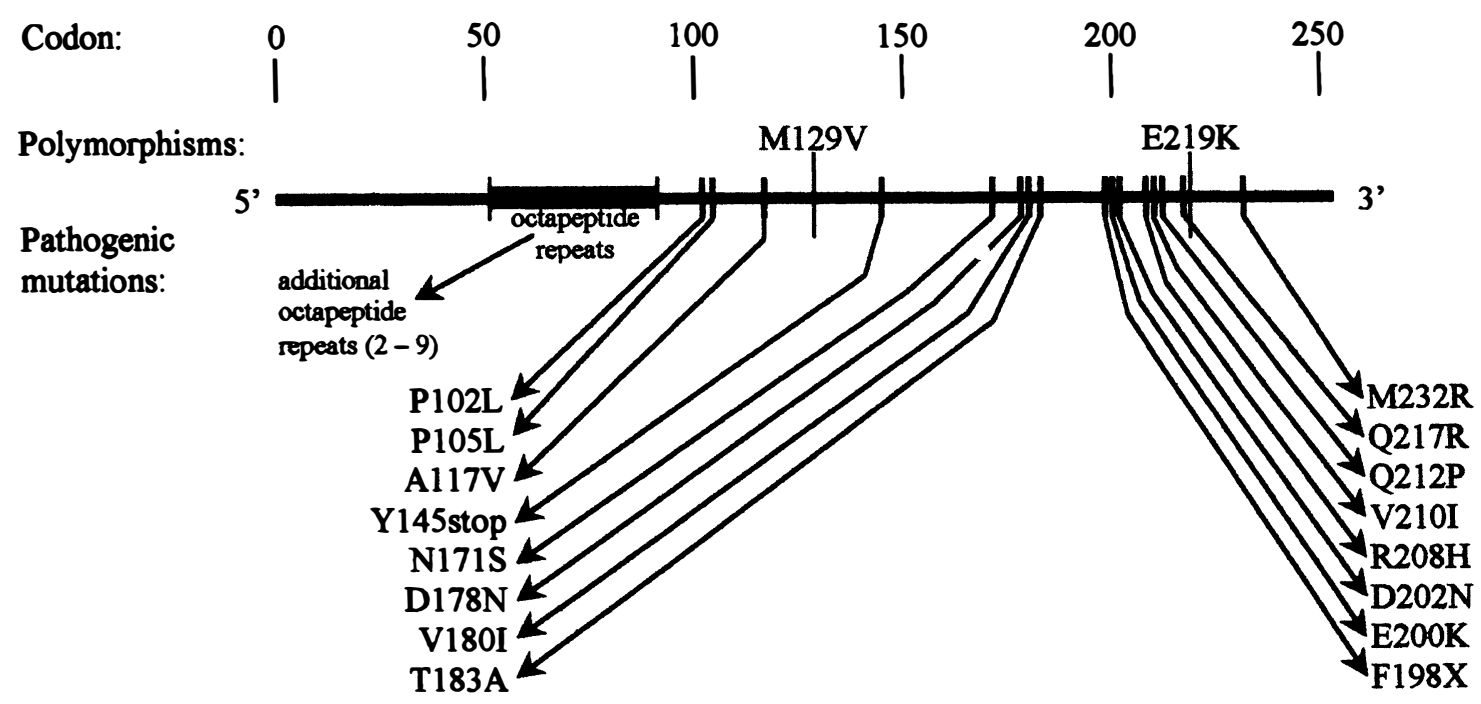

Fig. 2. Schematic representation of the human prion protein gene to show sites of known polymorphisms and pathogenic mutations. 'M129V' implies methionine replaced by valine at codon 129. Amino acid abbreviations are: $A$, alanine; $D$, aspartic acid; E, glutamic acid; $F$, phenylalanine; $H$, histidine; I, isoleucine; $K$, lysine; L, leucine; $M$, methionine; $N$, asparagine; $P$, proline; $Q$, glutamine; $R$, arginine; $S$, serine; $T$, threonine; $V$, valine; $Y$, tyrosine.

However, occasional cases of kuru still occur, and therefore, as cannibalism ceased in the late 1950s, the incubation period of kuru can extend beyond 30 years. ${ }^{176}$

\section{Genetics}

\section{Familial prion disease}

Worldwide, familial CJD represents some $10-15 \%$ of all cases of prion disease, ${ }^{56,64}$ but the incidence does seem to vary somewhat in different countries, from 0 in Austria, ${ }^{70} 6-12 \%$ in the UK, ${ }^{108,177} 9 \%$ in France, ${ }^{85} 35 \%$ in Libyan Jews, ${ }^{79,178}$ to between $17.5 \%$ and $47 \%$ in Chile. ${ }^{76,117}$ When familial, CJD is inherited as an autosomal dominant trait, but the percentage is age- and mutation-dependent, ${ }^{179,180}$ and may also depend on the genotype at codon 129 (see below).

The gene coding for PrP is located on short arm of chromosome $20 .{ }^{181}$ The first abnormality of the PrP gene was detected in $1989 .{ }^{182}$ There have been subsequent reports of many other genetic abnormalities related to inherited prion diseases, and several new ones now appear in the literature each year (see Fig. 2). At the time of writing this review, the current list of detected abnormalities includes two basic types. The first is that of insertions into the open reading frame of the gene (between codons 51 and 91). These insertions take the form of octapeptide repeats in addition to the five which are normally present. There can be an additional two, ${ }^{183}$ four, ${ }^{170}$ five, ${ }^{184}$ six (at least three types), ${ }^{182,185-190}$ seven, ${ }^{184,191}$ eight $^{25,184,192}$ or nine ${ }^{193,194}$ depending on the family involved.

The second type of abnormality is that of point mutations, which have been described at 16 different locations in the gene, in addition to the polymorphism at codon 129 (see below). There is an overall correlation between individual mutations and clinical patterns in each of the genetically different subsets. ${ }^{195,196}$ Mutations have been described in CJD and GSS at codons 102 (P102L), ${ }^{156,197-208} 105$ (P105L), ${ }^{209-211} 117$

(A117V), ${ }^{159,197,208,212,213} 145$ (Y145stop) ${ }^{214} 171$ (N171S), ${ }^{215}$ $178(\mathrm{D} 178 \mathrm{~N}),{ }^{166,216-222} 180$ (V180I) ${ }^{210,223} 183$ (T183A), ${ }^{224}$ 198 (F198S), ${ }^{225,226} 200$ (E200K), ${ }^{81,112,178-180,199,204,227-238}$ $202(\mathrm{D} 202 \mathrm{~N}){ }^{208} 208(\mathrm{R} 208 \mathrm{H}){ }^{239} 210(\mathrm{~V} 210 \mathrm{I}){ }^{235,240} 212$ $(\mathrm{Q} 212 \mathrm{P}){ }^{208} 217(\mathrm{Q} 217 \mathrm{R})^{208,226}$ and 232

(M232R). ${ }^{210,223,241,242}$ In FFI, the characteristic mutation is at codon $178(\mathrm{D} 178 \mathrm{~N})$, with methionine at codon 129 of the affected allele. ${ }^{163-166,168}$

The age of onset in familial CJD shows an extremely wide range, ${ }^{180,198,220,240}$ but the penetrance is probably $100 \%$, at least in the $\mathrm{D} 178 \mathrm{~N}^{220}$ and the $\mathrm{E} 200 \mathrm{~K}^{179,180}$ mutations. In families with the latter mutation, an earlier age of onset is more likely if there is an increased load of abnormal PrP, suggesting that normal PrP may be somewhat protective, but there must also be an agedependent factor since patients homozygous for E200K can remain well up to a certain age. ${ }^{243}$

Not all abnormalities of the PrP gene are pathogenic. Several deletions or silent mutations in the PrP gene have been found which seem not to confer genetic predisposition to prion disease. ${ }^{235,244}$ Further reviews of the genetics of TSEs can be found elsewhere. ${ }^{245}$

\section{Determinants of disease expression}

It appears that there are three main determinants of disease expression in prion diseases. These are the agent strain, the route of inoculation and the host PrP genotype. ${ }^{246}$ In animal studies an additional factor is that of the species barrier, ${ }^{247}$ which may be relevant to man, particularly in the case of vCJD. 
Table 3. Summary of all proven or highly probable cases of iatrogenic CJD

\begin{tabular}{|c|c|c|c|c|}
\hline Mode of infection & $\begin{array}{l}\text { No. of } \\
\text { patients }\end{array}$ & Agent entry into brain & $\begin{array}{l}\text { Mean incubation period } \\
\text { (range) }\end{array}$ & Clinical presentation $^{a}$ \\
\hline Stereotactic EEG & 2 & Intracerebral & 18 months $(16-20)$ & Dem/cereb \\
\hline Neurosurgery & 4 & Intracerebral & 20 months (15-28) & Vis/dem/cereb \\
\hline Corneal transplant & 3 & Optic nerve & 18 months $^{\mathrm{b}}$ (16 months-30 years) & 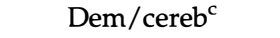 \\
\hline Dura mater graft & 83 & Cerebral surface & 6 years $(1.5-16)^{c}$ & Cereb (vis/dem) ${ }^{c}$ \\
\hline Gonadotrophin & 4 & Haematogenous & $13^{\mathrm{d}}$ years $(12-16)$ & Cerebellar \\
\hline Growth hormone & 98 & Haematogenous & 12 years $^{d}(5-30)^{c}$ & Cerebellar $^{c}$ \\
\hline
\end{tabular}

${ }^{\mathrm{a}}$ Dem, dementia; cereb, cerebellar; vis, visual.

${ }^{b}$ Median.

${ }^{\mathrm{c}}$ Although clinical information not available for all cases.

${ }^{\mathrm{d}}$ Calculated from the midpoint of hormone therapy to the onset of CJD symptoms.

\section{Strain}

Different 'strains' of the infective agent can be distinguished both on the grounds of reliable differences in incubation period and neuropathology following inoculation into panels of mice ('biological' strain), ${ }^{139,248}$ and by the electrophoretic mobility of the PrP and the glycosylation pattern ('molecular' strain). ${ }^{249,250}$ At least four different 'molecular' strains of human CJD have been reported to date. The first is associated with the typical CJD phenotype, the myoclonic variant and the Heidenhain variant, and is linked to the met/met genotype at codon 129 (see below). ${ }^{250}$ The second is associated with atypical and rarer variants such as dementia of long duration, the ataxic variant and a variant with kuru plaques. ${ }^{250}$ The third strain is associated with iatrogenic CJD where exposure has been by a peripheral route (e.g. human growth hormone) ${ }^{251}$ The fourth is associated with $\mathrm{vCJD},{ }^{249}$ and this strain is indistinguishable from that of BSE.

The existence of strains causes some difficulty with the 'protein only' prion hypothesis, ${ }^{35,143}$ but some authors argue that different protein conformational changes can explain the phenomenon $\left(\mathrm{see}^{44}\right)$.

\section{Route of inoculation}

In humans, when the infectious agent is introduced into, or near, the brain, the incubation period is measured in months, whereas peripheral inoculation (i.e. oral, intramuscular or intravenous) produces incubation period of years or decades ${ }^{252}$ (see Table 3). Similarly, the route of infection may be a determinant of the clinical pattern of the disease. ${ }^{7,252,253}$ In scrapie it has been shown that inoculation through non-neural, parenteral routes requires an obligatory phase of replication in the lymphoreticular system, and infection then spreads from spleen and visceral lymph nodes to the mid-thoracic cord via sympathetic nerves. ${ }^{254}$ Similar pathways are involved after intragastric infection. ${ }^{255,256}$

\section{PrP genotype}

At codon 129 of the PrP gene, there is a methionine/ valine (met/val) polymorphism. Seventy-one per cent of patients with sporadic CJD are homozygous for methionine compared with $39 \%$ of controls. ${ }^{257}$ The codon 129 polymorphism has also been shown to have an influence on pathology: the presence of at least one valine allele is associated with the presence of $\mathrm{PrP}$ amyloid plaques. ${ }^{258}$ Furthermore, patients with valine homozygosity tend to have a longer duration of illness, are more likely to present at a young age, and only rarely have periodic abnormalities on EEG. ${ }^{257}$ This may vary geographically as similar findings have not been reported in Japan. ${ }^{259}$ Codon 129 genotype is also an important component of the 'strain' of the CJD agent. ${ }^{260}$

In familial CJD and GSS, it appears that patients homozygous for met/met develop the disease earlier, ${ }^{186,202,225,240,261}$ though this is not a universal finding. ${ }^{207}$

In transmitted CJD, there is a great excess of patients homozygous at codon 129. All three patients with CJD transmitted by corneal transplantation were met/ met, ${ }^{262-264}$ and most tested cases developing CJD transmitted by cadaveric dura mater grafts were met/ met, ${ }^{265-267}$ though one was met/val ${ }^{268}$ and one val/ val. ${ }^{269} \mathrm{Val} / \mathrm{val}$ homozygosity is more common in patients developing CJD transmitted by human growth hormone, ${ }^{270-274}$ and the codon 129 genotype appears to influence incubation period. ${ }^{275}$ All patients with vCJD tested to date have been met/met homozygous. ${ }^{106,121-123,125}$ This may relate to the fact that bovine PrP shows no polymorphism, all animals being met/met homozygous: met/met homozygous humans may have increased susceptibility to bovine prions. ${ }^{145}$

A similar effect of a naturally occurring polymorphism at codon 219 has been reported in P102L GSS patients. Those patients with lysine at codon 219 have clearly different clinicopathological features from those with the usual glutamine. ${ }^{205}$

\section{Species barrier}

When TSEs are transmitted experimentally from one species to another, the incubation period is usually longer than that seen on subsequent passage within the new species. ${ }^{247,276}$ This effect is probably due to a combination of factors, including the efficiency of infection, agent strain selection, ${ }^{277,278}$ and possibly the compatibility of PrP proteins between animals. ${ }^{34}$ It has 
also been postulated that a species-specific protein (a chaperone protein, or protein $\mathrm{X}$ ) is required to facilitate the conformational change from $\operatorname{PrP}^{\mathrm{C}}$ to $\operatorname{PrP}^{\mathrm{Sc}},{ }^{279}$ though, as yet, there has been no direct identification of such a molecule. ${ }^{245}$

\section{Summary}

It appears that if an individual is exposed to CJD, whether or not that individual develops the disease may be influenced by their codon 129 genotype, with homozygosity somehow conferring increased susceptibility. The incubation period is likely to be determined by the mode of inoculation, as well as the strain type. The eventual clinical picture is probably determined by the strain type and route of inoculation. The effect of species barrier may be relevant to vCJD, as it may be that human-to-human transmission is more effective (by whatever means) than transmission from cow (BSE) to human. The implications of this are currently unknown, but much consideration is being given to possible modes of human-to-human transmission, such as surgical instruments, ${ }^{280}$ blood transfusion, ${ }^{281}$ contact lenses ${ }^{282}$ or tonometry.

\section{Investigations}

\section{Brain biopsy}

CJD shares many clinical features with other diseases. Hence, the differential diagnosis is large. A detailed review of this is beyond the scope of this article, but the interested reader may care to consult other authors regarding wider and more specific differential diagnostic lists. ${ }^{73,87,108,283-287}$ Short of autopsy, the gold standard for diagnosis remains histological examination of a brain biopsy. ${ }^{56,57,177}$ Specific diagnostic criteria have been established ${ }^{8}$ because spongiform change can occur in other conditions. ${ }^{7,288,289}$ However, brain biopsy is an invasive procedure, with consequent risks, and it may be falsely negative in up to $5 \%$ of cases. ${ }^{86,290,291}$ It is also costly in that it necessitates the destruction of surgical instruments (see below). Nevertheless, it remains the only way to diagnose CJD unequivocally during life; Western blot analysis of $\operatorname{PrP}$ in the brain biopsy allows identification of CJD strain, and this may have an important role in future assessment of CJD. ${ }^{292}$ In the meantime, non-invasive tests are being sought, and the WHO recommends that antemortem brain biopsy should not be used to diagnose CJD unless a potentially treatable disorder is also considered a possibility. ${ }^{86}$

\section{Electrophysiology}

\section{Electroencephalography (EEG)}

Abnormalities of the EEG were first described in 1953, ${ }^{293}$ and it is now accepted that the typical findings are of 1-2 $\mathrm{Hz}$ periodic sharp wave (simple biphasic or triphasic, or more complex polyspike) complexes (PSWCs) on a background of progressive increase in slow waves and loss of alpha rhythm..$^{53,294-309}$ This has now become part of the accepted criteria for clinical diagnosis. ${ }^{56,86,310}$ Nevertheless, though these abnormalities are seen in approximately $75 \%$ of patients ${ }^{60,82,87,108,311-314}$ (52\% in the UK; R.G. Will, personal communication), particularly if recorded serially, $311,315-317$ they are by no means diagnostic of $\mathrm{CJD}^{86,289}$ and are absent in $25 \%$ of pathologically proven cases of CJD. ${ }^{84,85,318-320}$ The changes are not seen in vCJD. ${ }^{106,125}$ Sleep EEG ${ }^{321}$ and brain mapping ${ }^{322}$ do not appear to aid diagnosis. The source of the PSWCs is not clear, but both cortical and subcortical structures are thought to be involved. 300,303,306

In the Heidenhain variant, the EEG may show occipital sharp and slow-wave complexes. ${ }^{91,323,324}$ It is of interest that photic-induced responses have been shown to abolish the PSWCs, possibly in relation to involvement of the lateral geniculate nucleus. ${ }^{325,326}$

\section{Other electrophysiology}

Visual evoked responses (VERs) often show no significant abnormality, $9,84,105,116,327-330$ but an exaggerated positive response has frequently been noted, ${ }^{303,307,331-336}$ possibly due to an exaggerated GABAergic inhibitory influence. ${ }^{337}$ Abnormally delayed VERs have occasionally been reported, ${ }^{100,105,338,339}$ but in at least one case the patient had coexistent multiple sclerosis, ${ }^{105}$ and in others the abnormalities may well have been due to poor fixation. ${ }^{100,338}$ Abnormal somatosensory evoked potentials have occasionally been recorded, $, 9,121,340$ and the blink reflex has also been reported to be abnormal. ${ }^{341}$

Electroretinography (ERG) has been reported to be abnormal in many cases of CJD transmitted by human growth hormone (hGH), ${ }^{341-344}$ though this is not always the case. ${ }^{331,333}$ A systematic study of ERG in CJD showed a significant decrease in amplitude of the $B 1$ wave and the $\mathrm{B} / \mathrm{A}$ ratio. ${ }^{335}$ Interestingly, histological studies on the human retina have shown spongiform changes in the nerve fibre layer, with loss of ganglion and bipolar cells, but few changes in the photoreceptors; $331,335,345,346$ photoreceptor abnormalities have, however, been detected in mice. ${ }^{347}$

\section{Imaging \\ Computed tomography (CT)}

CT imaging usually shows either no abnormality or just atrophy, $82,95,96,100,105,108,115,116,253,265,329,330,348-376$ but minor abnormalities have been described in the basal ganglia, $^{377}$ the white matter ${ }^{378-380}$ and in the occipital cortex, ${ }^{370}$ and one case study demonstrated progressive enlargement of the fourth ventricle. ${ }^{381}$ There is probably no consistent and reliable feature on $\mathrm{CT} .{ }^{382}$

\section{Magnetic resonance imaging (MRI)}

A number of different but inconsistent MRI abnormalities have been reported in CJD, including minor abnormalities of the caudate and 
putamen $^{91,236,323,362,364,369,374,376,377,383-391}$ (which may be asymmetric ${ }^{392}$ ), abnormalities of the

thalamus, ${ }^{107,125,362,393}$ occipital cortex (in the Heidenhain variant), ${ }^{91,101,323,370,394,395}$ white matter ${ }^{98,393,396}$

(particularly in the panencephalopathic type), ${ }^{100,101}$ or simply an excessive rate of cerebral atrophy. ${ }^{101,107,358}$

Careful retrospective analysis suggests that abnormalities of the basal ganglia may be found in $79 \%$ of patients if specifically sought. ${ }^{390}$ Alternatively, there may be just atrophy or no significant

abnormality. ${ }^{84,101,272,273,358,365,372,375,376,390,396-402}$ Contrast enhancement has not been observed. ${ }^{389,394}$

The above changes on MRI are neither specific ${ }^{390}$ nor sensitive ${ }^{382,401}$ but they may have a role in guiding biopsy. ${ }^{390}$ However, in vCJD, a very large proportion of patients show abnormalities of the pulvinar on MRI, ${ }^{127,128}$ and this may prove useful diagnostically. Also, newer sequences such as FLAIR ${ }^{403}$ or diffusionweighted $\mathrm{MRI}^{324,404-407}$ are showing abnormalities where routine MRI does not, and these may be useful in the future.

\section{Other imaging}

Isotope brain scans are unhelpful, ${ }^{82}$ as is magnetic resonance spectroscopy. ${ }^{396}$ Single photon emission computed tomography (SPECT) has been shown to reveal widespread decrease in cortical perfusion, 190,236,242,372,373,397,405,408-414 and may be useful in suggesting the diagnosis. ${ }^{415}$ Positron emission tomography (PET) using 2-[ $\left.{ }^{18} \mathrm{~F}\right]$ fluorodeoxyglucose has also shown diffuse cortical hypometabolism $355,366,367,375,416-418$ or posterior cortical hypometabolism in the Heidenhain variant. ${ }^{400,411,413}$ In FFI and SFI, PET scanning shows selective hypometabolism of the thalamus. ${ }^{171,419}$ None of these observations has so far provided a clinically useful test.

\section{Cerebrospinal fluid (CSF)}

Early reports on routine CSF examination in CJD found either no abnormality or just a slight elevation of CSF protein. ${ }^{53,77,82,87,102,103,108,115,116,302,329,350,420,421}$ Similar findings have been found in $\mathrm{FFI}^{162}$ and vCJD. ${ }^{125}$ Oligoclonal bands have occasionally been reported, ${ }^{339}$ probably coincidentally. Several potential markers have been looked at, including neuron-specific enolase, ${ }^{91,372,422-425}$ ubiquitin, ${ }^{426}$ lactic acid, ${ }^{427}$ T-protein, ${ }^{428}$ S-100 protein ${ }^{423,429-432}$ and inflammatory cytokines (TNF- $\alpha$ and IL-1 $\beta$ ), ${ }^{433}$ but none has been reported to show abnormalities sufficient to be the basis of a useful clinical test.

A different marker, originally described as proteins 130 and $131^{434}$ but subsequently termed $14-3-3$ protein, has shown more promise. It is found in patients with sporadic $^{290,425,435,436}$ and codon 200-related familial $\mathrm{CJD}^{437}$ with a high degree of specificity and sensitivity, though there can be false positives, in particular in patients with recent stroke, subarachnoid haemorrhage and viral encephalitis, and occasionally in a range of other conditions. ${ }^{86,151,438,439}$ There can also be false negatives, ${ }^{440}$ and the degree of sensitivity is not as high for vCJD. ${ }^{124,125}$ The exact role of 14-3-3 in normal brain is not clear, but it may have a role in signal transduction. ${ }^{441}$ It is not normally present in CSF, and seems to appear as a result of massive neuronal destruction. ${ }^{438}$

\section{Blood tests}

Elevated hepatic enzymes have been noted in some cases, ${ }^{44-444}$ but these abnormalities can be transient, or absent. ${ }^{445}$ Serum neopterin levels have been shown to be elevated in CJD, implying some cell-mediated immune system activation, but this test is not in any way specific. ${ }^{446}$ It has been suggested that the fact that $\operatorname{PrP}$ is present in blood monocytes ${ }^{447}$ might provide a useful test. ${ }^{44}$ However, if the abnormal form of PrP is expressed in the blood of affected individuals, the titre of infectivity is extremely low (see below). Much work is in progress to try to develop highly sensitive assays capable of detecting such extremely low levels of abnormal PrP.

\section{Other tests}

As in scrapie, ${ }^{448}$ abnormal $\operatorname{PrP}$ can be detected in the tonsils of patients with vCJD, ${ }^{449}$ but not in sporadic CJD or GSS. ${ }^{450}$ It has been suggested that tonsillar biopsy could be a useful diagnostic test, ${ }^{451}$ and even that it might obviate the need for brain biopsy, ${ }^{393}$ but this is by no means certain. ${ }^{452}$

In sheep, biopsy of the nictitating membrane ('third eyelid') has been advocated for the purpose of diagnosing scrapie, ${ }^{453}$ but this is not applicable to man.

An appendix removed 8 months before initial symptoms of vCJD was found to show abnormal PrP. This raises possibilities for assessing prevalence, as well as possible infectivity issues. ${ }^{454} \mathrm{~A}$ study of the prevalence of vCJD based on appendicectomy specimens is currently in progress.

\section{Transmission}

Transmission of TSEs has been documented to occur in man by various routes, and suggested to occur in others. A summary of the documented routes has been presented in Table 3, above.

\section{Neurological and hormonal transmission}

\section{Neurosurgery}

Following the first clear demonstration of human-tohuman transmission via corneal transplantation (see below) ${ }^{4}$ the next method of transmission to be firmly implicated was neurosurgery. Two patients developed CJD following a procedure using stereotactic EEG electrodes previously used on a patient who had CJD. ${ }^{455}$ The electrodes in question were subsequently shown to transmit the disease to a chimpanzee. ${ }^{456}$ Neurosurgical instruments have subsequently also been strongly 
implicated in several case reports, ${ }^{56,457,458}$ and there have been a few weaker associations with neurosurgery in general, e.g. in surgery for trigeminal neuralgia, ${ }^{58}$ resection of meningioma, ${ }^{459,460}$ cerebral abscess ${ }^{459}$ or leukotomy. ${ }^{459}$ An increased risk associated with general surgical operations has also been reported in a recent epidemiological study. ${ }^{280}$ However, the strongest association in neurosurgical practice has been with the use of cadaveric dura mater grafts (see below).

\section{Cadaveric dura mater homografts}

The first report that grafting of cadaveric dura mater might be responsible for the subsequent development of CJD was in $1987 .{ }^{461}$ Since that time there have been over 80 reports of CJD developing following the neurosurgical use of cadaveric dura mater (P. Brown, personal communication), ${ }^{253,265,266,269,368,462-473}$ some 26 cases having been recently reviewed. ${ }^{264}$ Dura mater has been shown in animal studies to transmit hamster scrapie, ${ }^{474}$ and several different types of CJD have developed, for example the panencephalopathic type ${ }^{267}$ and the Heidenhain variant, ${ }^{253,472}$ presumably depending somewhat on the site of the graft.

Interestingly, cadaveric dura mater has been implicated in the development of CJD in other circumstances, including using it to embolise a nasopharyngeal carcinoma ${ }^{268}$ or even an aspergilloma in the chest. ${ }^{402}$ Closely related is the development of CJD following the use of a pericardial membrane homograft to repair an eardrum. ${ }^{475}$

\section{Pituitary hormone therapy}

Cadaveric pituitary glands can be harvested to obtain pituitary hormones in high concentration. This technique has been used principally in treating short stature in children with human growth hormone $(\mathrm{hGH})$ and infertility in women with human pituitary gonadotrophin (hPG).

The fact that hGH was implicated in the subsequent development of CJD first came to light in $1985,{ }^{476}$ since which time there have been over 100 reports (P. Brown, personal communication), 132,272-274,330,338,343,344,378,409, 477-486 including an asymptomatic case which was found incidentally following death from pneumonia. ${ }^{487}$ The incidence of CJD has been suggested to be as high as $1 /$ 300 patients treated. ${ }^{484}$ These cases have been reviewed elsewhere. ${ }^{252,488-492}$ There are four reported cases due to hPG. ${ }^{365,398}$ As with cadaveric dura mater, it is possible to harvest pituitaries from patients who are asymptomatic but nevertheless incubating the disease, and, in the absence of a test for 'carrier' status, the possibility of infection is therefore never negligible. ${ }^{493}$ Pituitaryderived hGH is no longer used ${ }^{488}$ (except, perhaps, illicitly by bodybuilders ${ }^{494,495}$ ), genetically engineered sources being used instead. ${ }^{496}$

\section{Blood and other routes of transmission}

Blood

CJD has been transmitted to animals from human whole blood or buffy coat, ${ }^{212,251,497,498}$ a finding consistent with the observations that blood monocytes contain PrP in man $^{447}$ and animals, ${ }^{12}$ and that blood can transmit scrapie in animals. ${ }^{499,500}$ Nevertheless, there are a number of puzzling features, ${ }^{501}$ and about half of all studies of infectivity in blood have been negative, ${ }^{502}$ including assays in primates inoculated with human blood. ${ }^{73}$ There has therefore been much speculation about whether or not blood products might transmit the disease. ${ }^{281}$ This would, of course, have major implications for patients receiving all types of blood product, especially groups such as those with haemophilia. ${ }^{503}$ However, five epidemiological studies have shown no excess of prior blood transfusion in patients with CJD over controls, ${ }^{280,504-508}$ making transmission by blood transfusion, if it happens at all, a rare event. ${ }^{509}$

Patients who develop CJD have occasionally been demonstrated to have donated blood before developing the illness. ${ }^{501-515}$ This has caused concern, and in a few cases it has been suggested that CJD has, in fact, developed in some of the recipients, ${ }^{511,513,515}$ though a causal link has never been substantiated. ${ }^{516}$ In one case, 35 units of blood donated by a patient who subsequently developed CJD were traced to their recipients, and none of the recipients has so far developed CJD..$^{512}$

Nevertheless, it is clearly important that patients with known $\mathrm{CJD}^{517}$ or those at risk of developing the disease, ${ }^{518}$ do not donate blood, and extreme vigilance is required in general. ${ }^{501,519}$ In the UK, blood for transfusion is now routinely leucodepleted.

\section{Other routes of transmission}

Dietary transmission has long been suspected, with particular reference to eating sheep's eyeballs, ${ }^{520}$ raw meat, ${ }^{508}$ or the brains of various animals. ${ }^{508,521-527}$ However, most epidemiological studies have failed to show a significant effect of eating organs, including brain, ${ }^{507,528}$ in sporadic CJD. The association of vCJD with BSE has been discussed above, but, though often suggested, ${ }^{529}$ it is still not clear that the method of transmission is dietary.

Several other possibilites have been suggested for transmission, in particular procedures which involve lymphoid tissue such as tonsillectomy or appendicectomy, ${ }^{165}$ and, of course, blood products (see above) since it appears that the lymphoreticular system plays an important role in the propagation of infection following parenteral inoculation. ${ }^{530,531}$ Other medical procedures have been looked at retrospectively, including EMG, lumbar puncture and vaccination, and no increased risk of CJD has been found. ${ }^{508}$

As mentioned above, occupational exposure to animals or animal products has been suggested, ${ }^{133-136}$ but recent epidemiological work has shown no increased 
risk, except in the case of exposure to leather or fertiliser containing hoof and horn, ${ }^{508}$ findings of uncertain significance.

Dentistry has also been suggested as a potential risk, ${ }^{458}$ though this claim has not been supported by later studies. ${ }^{280}$ The possibility of vertical transmission (mother to child) has been considered, but has not occurred in three documented cases, ${ }^{455,469,498}$ nor has it been described in kuru. ${ }^{532}$ Curiously, one substantiated example of conjugal CJD (occurring in husband and wife) has been reported, ${ }^{533}$ and a recent report describes a cat and its owner both developing a TSE within months of each other. ${ }^{534}$ The significance of these cases is uncertain, and they may be purely coincidental.

\section{Transmission routes of ophthalmological relevance}

It has been shown experimentally that it is possible to transmit TSEs by inoculation of infected material into the eye. ${ }^{3,535,536}$ That the cornea is infectious has been demonstrated in various animals, ${ }^{537-539}$ including man. ${ }^{538,540}$ There are, in theory, two possible routes of entry into the brain following inoculation into the eye. The first is direct, via the visual pathways. ${ }^{541,542}$ The second involves peripheral spread via the blood following leakage of the inoculum from the infected eye. ${ }^{543}$ Both might be relevant to man.

\section{Corneal transplantation}

There have been three case reports in the literature describing human-to-human transmission of CJD via corneal transplantation. Of these, the first was in 1974, and this represents the only definite case of transmission by this route. The other two represent probable ${ }^{263}$ and possible ${ }^{544}$ cases of transmission. ${ }^{289}$ Occasionally, other ophthalmic procedures have been reported in patients who subsequently developed CJD, such as photocoagulation, ${ }^{56}$ cataract removal ${ }^{56}$ or prior surgery for congenital glaucoma, ${ }^{107}$ but these are probably incidental findings and will not be discussed further. The cases involving corneal transplantation will be dealt with in more detail.

- Duffy et al. ${ }^{4,545}$ described the case of a cadaveric corneal graft, the donor being a 55-year-old man with a 2 month history of ataxia, memory deficit, myoclonus and involuntary movements who was later found to have pathologically confirmed CJD. The recipient was a 55-year-old woman with Fuchs' corneal dystrophy who developed symptoms of lethargy, nausea and ataxia some 18 months after surgery, and died after a further 9 months. Not only was she confirmed to have died from CJD at post-mortem, ${ }^{73}$ but a homogenate of her brain subsequently produced CJD when injected into a chimpanzee. ${ }^{73}$ Though the transplanted cornea itself was not retained for study, this is generally accepted to be a definite case of transmission. ${ }^{73,289}$
- Uchiyama et al. ${ }^{544}$ described the case of a 63 -year-old woman who developed autopsy-proven CJD 15 months following a corneal transplant. Unfortunately, details of the donor were not given, so this must be regarded as a possible case of transmission. ${ }^{289}$

- Heckmann et al. ${ }^{263}$ described the clinical features of CJD 30 years following corneal transplantion from a donor who had a 3 month history of incoordination, memory loss, involuntary movements and myoclonic jerks whose autopsy later confirmed CJD. Unfortunately, while the recipient developed a rapidly progressive cerebellar syndrome with dementia and myoclonic jerks, and the EEG was typical, no histological proof of the diagnosis of CJD was ever obtained, so this must remain a probable case of transmission. ${ }^{289}$

Any patient having received a corneal transplant presenting with cerebellar signs, gait disorder, mental deterioration, dysarthria, visual/oculomotor signs, myoclonus and/or pyramidal signs should be suspected of having CJD. ${ }^{264}$

Recently, ocular tissue from a donor later found to have sporadic CJD was transplanted into three separate patients, ${ }^{546}$ an event considered sufficiently newsworthy to be reported in the London Times ${ }^{547}$ and the medical press $^{548}$ at the time, and to be the subject of a report commissioned by the Royal College of Ophthalmologists. ${ }^{549}$ In fact, the donor was known to be terminally ill from a known carcinoma of the lung, and it was not until some 8 months later that examination of her brain revealed CJD. ${ }^{550}$ In retrospect, she had had a few weeks' history of odd gait and memory disturbance prior to her death, but this was presumed to have been due to cerebral secondaries. The recipients have subsequently had their grafts removed, but their future remains uncertain some two and a half years after surgery. This case highlights how important it is that guidelines as to which patients should not have their corneas harvested for transplantation are widely available and adhered to ${ }^{551}$ (see below).

The possibility of transmission of CJD by corneal transplantation has been previously reviewed. ${ }^{552,553}$ It has been suggested that in the USA, based on statistics from the Eye Bank Association of America, at most 4.2 cases of CJD would be available to donate their corneas each year. This represents less than $0.01 \%$ of all donors, and the authors conclude that the relative risk of transmitting CJD is therefore minute compared with the benefit conferred to transplant recipients' sight. ${ }^{289}$ The low level of risk has been compared with that of other hazards, such as death from general anaesthetic. ${ }^{546}$ Strictly speaking, the above calculations do not include patients who might possibly be incubating vCJD. The number of such persons is unknown, but the possibility of transmission of vCJD via blood has resulted in the policy of leucodepletion (see above). There may be a similar difference between CJD and vCJD with respect to corneal transmissibility. 


\section{Applanation tonometry}

In view of the known infectivity of the eye, the possibility that applanation tonometry might transmit the disease has been suggested, ${ }^{554-556}$ and one group has consistently found that patients with CJD were significantly more likely to have had tonometry in the past. ${ }^{554,555,557}$ This has not always been found, ${ }^{59,66}$ and it has been suggested that the large odds ratio may be related to the fact that many patients have tonometry for visual symptoms during the prodrome of their illness. ${ }^{558}$ Recent case-control studies have shown no increased risk of previous eye surgery, ${ }^{507,508}$ and one found no increased risk of previous ophthalmological examination, presumably including tonometry. ${ }^{508}$

\section{Transmission to medical/paramedical personnel}

Epidemiological studies have sometimes reported an excess of cases of CJD among health care workers, including nurses, physicians and dentists, ${ }^{56,64,66}$ though the difference is not always significant. ${ }^{66}$ This is nevertheless potentially worrying, and there have been specific case reports of CJD occurring in a neurosurgeon, ${ }^{559}$ a neuropathologist, ${ }^{416}$ two histopathology technicians, ${ }^{560,561}$ a physician who trained as pathologist, ${ }^{562}$ a general surgeon who worked in a pathology department ${ }^{563}$ and an orthopaedic surgeon who handled dura mater. ${ }^{564}$ However, the largest epidemiological study to date ${ }^{508}$ and a metaanalysis of previous case-control studies, ${ }^{507}$ have shown no excess risk to health workers at all. To our knowledge, there have been no reported cases of CJD occurring in ophthalmologists.

\section{Management}

Guidelines for various procedures were issued as early as 1974 (cerebral biopsies), ${ }^{565} 1975$ (autopsies) ${ }^{566}$ and 1977 (patient handling) ${ }^{567}$ More up-to-date consensus statements have recently been issued. ${ }^{310,568,569}$ Specific aspects dealing with ophthalmic practice are dealt with below, but further guidelines can be found in a publication by the Advisory Committee on Dangerous Pathogens. ${ }^{569}$

\section{Management of patients}

\section{Ward management}

Epidemiological evidence suggests that, from the general point of view, patients with, or suspected of having, TSEs can be nursed on an open ward. There is no evidence of infectivity in saliva, body secretions or excreta, and these should therefore be treated as potentially infectious in line with standard infection control procedures. ${ }^{569}$ When nursing such patients, disposable items should be used wherever possible and incinerated afterwards. For sampling and processing of biological specimens, personnel should use gowns, gloves, masks and eye protection. Catheters and needles should be destroyed.
Pins used for routine testing of pain sensation must be discarded after use in any patient. Potentially contaminated biological products, including secretions, blood, CSF and other body fluids, should be incinerated. ${ }^{570}$

Should a needle-stick injury occur, or an abrasion be contaminated with blood or body fluids, current guidelines are that the wound should be gently encouraged to bleed, gently washed with warm soapy water (avoiding scrubbing), rinsed, dried and covered with a waterproof dressing. Splashes into the eye or mouth should be dealt with by thorough irrigation. ${ }^{569}$ Various suggestions have been put forward for more active treatment following inoculation with a TSE agent, including excision and treatment with oral steroids: prednisolone $60 \mathrm{mg}$ a day for 7 days followed by $45 \mathrm{mg}$ a day for 7 days, ${ }^{571}$ or dextran sulphate (molecular weight $500 \mathrm{kDa}) 400 \mathrm{mg} / \mathrm{kg}$ intramuscularly or oral doses of pentosan polysulphate $1200 \mathrm{mg}$ daily for 3 months. ${ }^{572}$

Management of known or suspected cases during ophthalmic surgery

While there have only been three reported instances of ophthalmologically transmitted CJD, ${ }^{4,263,544}$ it remains theoretically possible that CJD might be transmitted via ophthalmic operating instruments. The UK CJD Surveillance Unit is aware of five patients with CJD who had intraocular surgery during their prodromal phase during the years 1990-1995 (R.G. Will, personal communication). By analogy with neurosurgical instruments, there is a theoretical risk that CJD might be transmitted by ophthalmic instruments used on such patients.

The possibility of transfer of CJD by operating equipment was noted as early as $1977,{ }^{567}$ and guidelines as to the use of instruments were suggested then and subsequently. ${ }^{567,569,570,573-578}$ A synthesis of the guidelines would suggest that during operations on the eye on known, suspect or at risk patients:

- the least possible number of persons should take part in the operation, and those present should wear waterproof gowns, gloves, and face masks with transparent plastic visors to protect the eyes;

- the operation should take place at the end of the list;

- a one-way flow of instruments should be maintained;

- where possible, disposable equipment should be used;

- in suspected cases, instruments which have been in contact with the patient should either be destroyed or quarantined until the diagnosis is confirmed or refuted (and destroyed if the diagnosis is confirmed).

Ophthalmic and neuro-ophthalmic features are discussed in the accompanying paper. ${ }^{2}$

It has been suggested that the costs involved in destroying instruments are likely to be small, as extremely few patients will be involved, ${ }^{577}$ and one possible method of coping with the problem is to have a dedicated set of instruments, as has been advocated in neurosurgical practice. ${ }^{291}$ 
From the anaesthetic viewpoint, guidance differs. The UK Advisory Committee on Dangerous Pathogens (ACDP) states that all instruments should be destroyed when used on suspect or known cases. ${ }^{569}$ Elsewhere, it has been recommended that all disposable equipment be destroyed and that the laryngoscope be sterilised by immersion in a 5\% sodium hypochlorite solution for 1 hour. ${ }^{570}$ For 'at risk' groups, the ACDP allows for reuse of instruments used outside the central nervous system (CNS) if they are properly decontaminated. ${ }^{569}$

\section{Selection of donors for corneal transplantation}

The potential for contamination through grafting any tissue depends on five things: ${ }^{579}$

- the nature of the donor organ;

- the stage of the infection of the donor at the time of the graft;

- the screening of the donor;

- the nature of the surgery associated with the graft process;

- the physical or chemical treatment which might be applicable to the graft.

With respect to corneal transplantation, the potential for the cornea to transmit CJD is well established, ${ }^{4,263,544}$ as is the relatively high infectivity of the eye itself. ${ }^{538,540}$ Treatments which would render a cornea non-infective would almost certainly damage its optical properties, and are therefore not applicable. The only way to reduce the likelihood of transmission, therefore, is to screen potential donors, and to reject any who are, or might be, symptomatic from CJD or at risk of developing the disease. However, this will still not exclude the possibility of iatrogenic transmission completely: patients may be asymptomatic for a period before developing overt clinical features, and during this stage there is no effective screening test. Such patients are still potentially infective.

One potential solution would be to cease corneal transplantation altogether, but this seems totally inappropriate ${ }^{553}$ granted that the potential number of donors who might harbour CJD is extremely small, ${ }^{576}$ one study calculating it to be between $0.005 \%$ and
$0.009 \% .{ }^{289}$ Accordingly, guidelines have been issued regarding the rejection of potential donors. ${ }^{580}$ The European Eye Bank Association has provided guidelines for several years, and these are available in the UK through the Royal College of Ophthalmologists (www.rcophth.ac.uk). If these are followed, the risk of transmitting CJD has been considered to be acceptable compared with the potential benefits to sight in corneal recipients. ${ }^{553}$

In summary, the following should not be considered as potential donors:

- Any patient with known CJD, GSS or FFI, or any form of degenerative dementia or subacute encephalopathy. ${ }^{546,579}$

- Any patient dying of unknown cause, ${ }^{553}$ or suffering from CNS disease of unknown aetiology. ${ }^{289}$

- Any recipient of human cadaveric pituitary-derived hormones. ${ }^{488,553,576,579}$

- Any recipient of a human dura mater graft. ${ }^{576}$ Note that detecting such patients may be difficult because most recipients are not aware that they have received a dural graft. Extending this group to all those who have undergone a neurosurgical procedure would eliminate the vast majority of dural graft recipients but could be too restrictive.

- Any patient belonging to a family with CJD, GSS or FFI. ${ }^{546,576,579,581,582}$ The degree of blood relativity is a matter of debate, but should probably include at least sibling, parent, grandparent, child or grandchild. The UK Transplant Support Service routinely asks whether a post-mortem is pending on a potential donor; if it is, no tissue is issued until the results of that postmortem are known. ${ }^{551}$ A negative histological examination of a small piece of frontotemporal cortex from any cadaver used as a source of tissue grafts would add reassurance and has been recommended for dural graft donors in the United States. However, whether this would be practical for all corneal donors is a matter for debate. ${ }^{582}$

Table 4. Decontamination procedures ${ }^{310,474,569,573,574,579,584,585}$






\section{Management of instruments}

Prions are resistant to almost all the procedures generally used to inactivate conventional viruses. Effective and ineffective methods of decontamination are given in Table 4.

In the case of corneal transplantation, it is possible to use only disposable instruments in harvesting corneas from donors, and in the subsequent processing during eye banking. Similarly, disposable corneal trephines and blocks can be used. These procedures would seem sensible to minimise any potential risk of transmitting CJD via instruments.

Rizzo and colleagues ${ }^{558}$ raised concern about the transmission of CJD by applanation tonometry following three of their patients undergoing this procedure for visual symptoms during the prodrome of CJD, and suggested that disposable heads should be used. Even though a significant association of CJD with intraocular pressure monitoring has occasionally been noted (see above), the American Neurological Association Committee on Health Care Issues report on handling of affected materials ${ }^{574}$ did not mention tonometer heads. ${ }^{556}$ Nevertheless, routine decontamination would seem sensible ${ }^{554,555,557}$ and, for definite, suspected- or at-risk cases, it would be appropriate to use disposable tonometer heads, or an electronic tonometer with a disposable rubber diaphragm (e.g. a Tonopen). The UK Government's Spongiform Encephalopathy Advisory Committee has recently recommended that opticians dispose of trial contact lenses after each use because of the risk of transmitting vCJD. ${ }^{583}$ This may also have implications for the use of disposable tonometer heads in routine applanation tonometry in the UK.

\section{Summary}

This article attempts to summarise our current understanding of TSEs as they affect man. Specific aspects relevant to ophthalmological practice, in particular the management of patients in day-to-day clinical practice and with respect to corneal transplantation, have been discussed. In the companion article $^{2}$ we discuss the specific ophthalmic and neuroophthalmic features of these diseases.

\section{Appendix. List of abbreviations used}

$\begin{array}{ll}\text { ACDP } & \text { Advisory Committee on Dangerous Pathogens } \\ \text { BSE } & \text { Bovine spongiform encephalopathy } \\ \text { CJD } & \text { Creutzfeldt-Jakob disease } \\ \text { CSF } & \text { Cerebrospinal fluid } \\ \text { CT } & \text { Computed tomography } \\ \text { EEG } & \text { Electroencephalogram/electroencephalography } \\ \text { ERG } & \text { Electroretinogram/electroretinography } \\ \text { FFI } & \text { Fatal familial insomnia } \\ \text { GSS } & \text { Gerstmann-Sträussler-Scheinker disease } \\ \text { hGH } & \text { Human growth hormone } \\ \text { hPG } & \text { Human pituitary gonadotrophin } \\ \text { met } & \text { Methionine } \\ \text { MBM } & \text { Meat and bone meal } \\ \text { MRI } & \text { Magnetic resonance imaging }\end{array}$

PET Positron emission tomography

PrP Prion protein

PSWC Periodic sharp wave complexes

SFI Sporadic fatal insomnia

SPECT Single photon emission computed tomography

TSE Transmissible spongiform encephalopathy

CJD (new) Variant Creutzfeldt-Jakob disease

val Valine

VER Visual evoked response

WHO World Health Organization

\section{References}

1. Gray M. Evidence-based healthcare: the 21st-century agenda. MRC News 1998;79:34-7.

2. Lueck CJ, Mcllwaine GG, Zeidler M. Creutzfeldt-Jakob disease and the eye. II. Ophthalmic and neuro-ophthalmic features. Eye 2000;14:291-301.

3. Cuillé J, Chelle P-L. Pathologie animale: la maladie dite tremblante du mouton est-elle inoculable? C R Acad Sci 1936;203:1552-4.

4. Duffy P, Wolf J, Collins G, DeVoe AG, Streeten B, Cowen D. Possible person-to-person transmission of Creutzfeldt-Jakob disease. N Engl J Med 1974;290:692-3.

5. Brown P. A therapeutic panorama of the spongiform encephalopathies. Antiviral Chem Chemother 1990;1:75-83.

6. Masters CL, Richardson EP. Subacute spongiform encephalopathy (Creutzfeldt-Jakob disease). The nature and progression of spongiform change. Brain 1978;101:333-44.

7. Bell JE, Ironside JW. Neuropathology of spongiform encephalopathies in humans. Br Med Bull 1993;49:738-77.

8. Budka H, Aguzzi A, Brown P, et al. Neuropathological diagnostic criteria for Creutzfeldt-Jakob disease (CJD) and other human spongiform encephalopathies (prion diseases). Brain Pathol 1995;5:459-66.

9. Landis DMD, Williams RS, Masters CL. Golgi and electronmicroscopic studies of spongiform encephalopathy. Neurology 1981;31:538-49.

10. McKinley MP, Bolton DC, Prusiner SB. A protease-resistant protein is a structural component of the scrapie prion. Cell 1983;35:57-62.

11. Brown P, Goldfarb LG, Gajdusek DC. The new biology of spongiform encephalopathy: infectious amyloidoses with a genetic twist. Lancet 1991;337:1019-22.

12. Bendheim PE, Brown HR, Rudelli RD, et al. Nearly ubiquitous tissue distribution of the scrapie agent precursor protein. Neurology 1992;42:149-56.

13. Pan K-M, Baldwin M, Nguyen J, et al. Conversion of $\alpha$-helices into $\beta$-sheets features in the formation of the scrapie prion proteins. Proc Natl Acad Sci USA 1993;90:10962-6.

14. Stahl N, Borchelt DR, Hsaio K, Prusiner SB. Scrapie prion protein contains a phosphatidylinositol glycolipid. Cell 1987;51:229-40.

15. DeArmond SJ, Mobley WC, DeMott DL, Barry RA, Beckstead JH, Prusiner SB. Changes in the localization of brain prion proteins during scrapie infection. Neurology 1987;37:1271-80.

16. Borchelt DR, Koliatsos VE, Guarnieri M, Pardo CA, Sisodia SS, Price DL. Rapid anterograde axonal transport of the cellular prion glycoprotein in the peripheral and central nervous systems. J Biol Chem 1994;269:14711-4.

17. Askanas V, Bilak M, Engel WK, Leclerc A, Tomé F. Prion protein is strongly immunolocalized at the postsynaptic domain of human normal neuromuscular junctions. Neurosci Lett 1993;159:111-4.

18. Kristensson K, Feurerstein B, Taraboulos A, Hyun WC, Prusiner SB, DeArmond SJ. Scrapie prions alter receptormediated calcium responses in cultured cells. Neurology 1993;43:2335-41. 
19. Collinge J, Whittingon MA, Sidle KCL, et al. Prion protein is necessary for normal synaptic function. Nature 1994;370:295-7.

20. Whittingon MA, Sidle KC, Gowland I, et al. Rescue of neurophysiological phenotype seen in PrP null mice by transgene encoding human prion protein. Nature Genet 1995;9:197-201.

21. Brown DR, Besinger A. Prion protein expression and superoxide dismutase activity. Biochem J 1998;334:423-9.

22. Prusiner SB. Genetic and infectious prion diseases. Arch Neurol 1993;50:1129-53.

23. Gibbs CJ, Gajdusek DC, Asher DM, et al. Creutzfeldt-Jakob disease (spongiform encephalopathy): transmission to the chimpanzee. Science 1968;161:388-9.

24. Chapman J, Brown P, Rabey JM, et al. Transmission of spongiform encephalopathy from a familial Creutzfeldt-Jakob disease patient of Jewish Libyan origin carrying the PRNP codon 200 mutation. Neurology 1992;42:1249-50.

25. Goldfarb LG, Brown P, Vrbovská A, et al. An insert mutation in the chromosome 20 amyloid precursor gene in a Gerstmann-Sträussler-Scheinker family. J Neurol Sci 1992;111:189-94.

26. Masters CL, Gajdusek DC, Gibbs CJ. Creutzfeldt-Jakob disease virus isolations from the Gerstmann-Sträussler syndrome with an analysis of the various forms of amyloid plaque deposition in the virus-induced spongiform encephalopathies. Brain 1981;104:559-88.

27. Kimberlin RH, Hunter GD. DNA-synthesis in scrapieaffected mouse brain. J Gen Virol 1967;1:115-24.

28. Hope J. The nature of the scrapie agent: the evolution of the virino. Ann NY Acad Sci 1994;724:289.

29. Bolton DC, McKinley MP, Prusiner SB. Identification of a protein that purifies with the scrapie prion. Science 1982;218:1309-11.

30. Prusiner SB. Novel proteinaceous infectious particles cause scrapie. Science 1982;216:136-44.

31. Prusiner SB. Molecular biology of prion diseases. Science 1991;252:1515-21.

32. DeArmond SJ, Prusiner SB. Etiology and pathogenesis of prion diseases. Am J Pathol 1995;146:785-811.

33. Prusiner SB. Scrapie prions. Annu Rev Microbiol 1989;43:345-74.

34. Prusiner SB, Scott M, Foster D, et al. Transgenetic studies implicate interactions between homologous PrP isoforms in scrapie prion replication. Cell 1990;63:673-86.

35. Weissmann C. The prion's progress. Nature 1991;349:569-71.

36. Prusiner SB. Prions. Proc Natl Acad Sci USA 1998;95:13363-83.

37. Forloni G, Angeretti N, Chiesa R, et al. Neurotoxicity of prion protein fragment. Nature 1993;362:543-6.

38. Forloni G, Angeretti N, Malesani $P$, et al. Influence of mutations associated with familial prion-related encephalopathies on biological activity of prion protein peptides. Ann Neurol 1999;45:489-94.

39. Prusiner SB, Groth D, Serban A, et al. Ablation of the prion protein $(\operatorname{PrP})$ gene in mice prevents scrapie and facilitates production of anti-PrP antibodies. Proc Natl Acad Sci USA 1993;90:10608-12.

40. Gajdusek DC. Nucleation of amyloidogenesis in infectious and noninfectious amyloidoses of the brain. Ann NY Acad Sci 1994;724:173-90.

41. Prusiner SB. Prions and neurodegenerative diseases. N Engl J Med 1987;317:1571-81.

42. Goldfarb LG, Brown P. The transmissible spongiform encephalopathies. Annu Rev Med 1995;46:57-65.

43. Haywood AM. Transmissible spongiform encephalopathies. N Engl J Med 1997;337:1821-8

44. Prusiner SB. Prion diseases and the BSE crisis. Science 1997;278:245-51.
45. Johnston RT, Gibbs CJ. Creutzfeldt-Jakob disease and related transmissible spongiform encephalopathies. N Engl J Med 1998;339:1994-2004.

46. Creutzfeldt HG. Über eine eigenartige herdförmige Erkrankung des Zentralnervensystems. Z Ges Neurol Psych 1920;57:1-18.

47. Jakob A. Über eigenartige Erkrankungen des Zentralnervensystems mit bemerkenswertem anatomischen Befunde (spastische Pseudosklerose Encephalomyelopathie mit disseminierten Degenerationsherden). Z Ges Neurol Psych 1921;64:147-288.

48. Jakob A. Über eine der multiplen Sklerose klinisch nahestehende Erkrankung des Zentralnervensystems (spastische Pseudoskerlose) mit bemerkenswertem anatomischem Befunde. Mitteilung eines vierten Falles. Med Klin 1921;17:372-6.

49. Jakob A. Die extrapyramidalen Erkrankungen, mit besonderer Berücksichtigung der pathologischen Anatomie und Histologie und der Pathophysiologie der Bewegungsstörungen. Monogr Psychiat (Berlin) 1923;37:215-45.

50. Spielmeyer W. Die histopathologische Forschung in der Psychiatrie. Klin Wochenschr 1922;1:1817-9.

51. Fischer O. Der spongiöse Rindenschwund; ein besondere Destruktionsprozess der Hirnrinde. Z Ges Neurol Psych 1911;7:1-33.

52. Richardson EP, Masters CL. The nosology of Creutzfeldt-Jakob disease and conditions related to the accumulation of PrPCJD in the nervous system. Brain Pathol 1995;5:33-41.

53. May WW. Creutzfeldt-Jakob disease. 1. Survey of the literature and clinical diagnosis. Acta Neurol Scand 1968;44:1-32.

54. Kirschbaum WR. Jakob-Creutzfeldt disease. New York: American Elsevier, 1968.

55. Gibbs CJ, Masters CL, Gajdusek DC. Bibliography of Creutzfeldt-Jakob disease. Bethesda: US Department of Health, Education and Welfare, Public Health Service, National Institutes of Health, 1979:149-52.

56. Masters CL, Harris JO, Gajdusek DC, Gibbs CJ, Bernoulli C, Asher DM. Creutzfeldt-Jakob disease: patterns of worldwide occurrence and the significance of familial and sporadic clustering. Ann Neurol 1979;5:177-88.

57. Kretzschmar HA, Ironside JW, DeArmond SJ, Tateishi J. Diagnostic criteria for sporadic Creutzfeldt-Jakob disease. Arch Neurol 1996;53:913-20.

58. Matthews, WB. Epidemiology of Creutzfeldt-Jakob disease in England and Wales. J Neurol Neurosurg Psychiatry 1975;38:210-3.

59. Brown P, Cathala F. Creutzfeldt-Jakob disease in France: I. Retrospective study of the Paris area during the ten-year period 1968-1977. Ann Neurol 1979;5:189-92.

60. Brown P, Cathala F, Sadowsky D, Gajdusek DC. Creutzfeldt-Jakob disease in France. II. Clinical characteristics of 124 consecutive verified cases during the decade 1968-1977. Ann Neurol 1979;6:430-7.

61. Brown P, Cathala F, Gajdusek DC. Creutzfeldt-Jakob disease in France. III. Epidemiological study of 170 patients dying during the decade 1968-1977. Ann Neurol 1979;6:438-46.

62. Cathala F, Brown P, Castaigne P, Gajdusek DC. La maladie de Creutzfeldt-Jakob en France continentale. Étude rétrospective de 1968 à 1977. Rev Neurol (Paris) 1979;135:439-54.

63. Will RG. Epidemiology of Creutzfeldt-Jakob disease. Br Med Bull 1993;49:960-70.

64. Brown P, Cathala F, Raubertas RF, Gajdusek DC, Castaigne $P$. The epidemiology of Creutzfeldt-Jakob disease: conclusion of a 15-year investigation in France and review of the world literature. Neurology 1987;37:895-904. 
65. Masullo C, Pocchiari M, Neri G, et al. A retrospective study of Creutzfeldt-Jakob disease in Italy (1972-1986).

Eur J Epidemiol 1988;4:482-7.

66. Harries-Jones R, Knight R, Will RG, Cousens S, Smith PG, Matthews WB. Creutzfeldt-Jakob disease in England and Wales, 1980-1984: a case-control study of potential risk factors. J Neurol Neurosurg Psychiatry 1988;51:1113-9.

67. Desgrandchamps D, Rieder HL, Marti B. Incidence of Creutzfeldt-Jakob disease. Lancet 1994;343:1229.

68. Delasnerie-Lauprêtre N, Poser S, Pocchiari M, Wientjens DPWM, Will R. Creutzfeldt-Jakob disease in Europe. Lancet 1995;346:898.

69. Hofman A, Wientjens DPWM. Epidemiological evidence concerning a possible causal link. BMJ 1995;311:1418-9.

70. Hainfellner JA, Jellinger $\mathrm{K}$, Diringer $\mathrm{H}$, et al. Creutzfeldt-Jakob disease in Austria. J Neurol Neurosurg Psychiatry 1996;61:139-42.

71. Lundberg PO. Creutzfeldt-Jakob disease in Sweden. J Neurol Neurosurg Psychiatry 1998;65:836-41.

72. Davanipour Z, Smoak C, Bohr T, Sobel E, Liwnicz B. Rate of Creutzfeldt-Jakob disease in USA. Neurology 1993;43:A316.

73. Brown P, Gibbs CJ, Rodgers-Johnson P, et al. Human spongiform encephalopathy: the National Institutes of Health series of 300 cases of experimentally transmitted disease. Ann Neurol 1994;35:513-29.

74. Holman RC, Khan AS, Kent J, Strine TW, Schonberger LB. Epidemiology of Creutzfeldt-Jakob disease in the United States, 1979-1990: analysis of national mortality data. Neuroepidemiology 1995;14:174-81.

75. Kahana E, Alter M, Braham J, Sofer D. Creutzfeldt-Jakob disease: focus among Libyan Jews in Israel. Science 1974;183:90-1.

76. Galvez S, Masters C, Gajdusek DC. Descriptive epidemiology of Creutzfeldt-Jakob disease in Chile. Arch Neurol 1980;37:11-4.

77. Tsuji S, Kuroiwa Y. Creutzfeldt-Jakob disease in Japan. Neurology 1983;33:1503-6.

78. Nakamura Y, Yanagawa H, Hoshi K, Yoshino H, Urata J, Sato T. Incidence rate of Creutzfeldt-Jakob disease in Japan. Int J Epidemiol 1999;28:130-4.

79. Neugut RH, Neugut AI, Kahana E, Stein Z, Alter M. Creutzfeldt-Jakob disease: familial clustering among Libyan-born Israelis. Neurology 1979;29:225-31.

80. Zilber N, Kahana E, Abraham M. The Libyan Creutzfeldt-Jakob disease focus in Israel: an epidemiologic evaluation. Neurology 1991;41:1385-9.

81. Gabizon R, Rosenman H, Meiner Z, et al. Mutation in codon 200 and polymorphism in codon 129 of the prion protein gene in Libyan Jews with Creutzfeldt-Jakob disease. Phil Trans R Soc Lond B 1994;343:385-90.

82. Will RG. The epidemiology of Creutzfeldt-Jakob disease [thesis]. 1984. University of Cambridge.

83. Wientjens DPWM. Epidemiology of Creutzfeldt-Jakob disease: incidence, risk factors and survival in European studies [thesis]. 1997. University of Rotterdam.

84. Berman PH, Davidson GS, Becker LE. Progressive neurological deterioration in a 14 -year-old girl. Paediatr Neurosci 1988;14:42-9.

85. Brown P, Cathala F, Castaigne P, Gajdusek DC. Creutzfeldt-Jakob disease: clinical analysis of a consecutive series of 230 neuropathologically verified cases. Ann Neurol 1986;20:597-602.

86. World Health Organization. Global surveillance, diagnosis and therapy of human transmissible spongiform encephalopathies: report of a WHO consultation. WHO/ EMC/ZDI/98.9. Geneva: World Health Organization, 1998.

87. Roos R, Gajdusek DC, Gibb CJ. The clinical characteristics of transmissible Creutzfeldt-Jakob disease. Brain 1973;96:1-20.

88. De Silva R. Human spongiform encephalopathy. In: Baker HF, Ridley RM, editors. Methods in molecular medicine: prion diseases. Totowa, NJ: Humana Press, 1996:15-33.
89. Heidenhain A. Klinische und anatomische Untersuchungen über eine eigenartige organische Erkrankung des Zentralnervensystems in Praesenium. Z Ges Neurol Psych 1928;118:49-114.

90. Meyer A, Leigh D, Bagg CE. A rare presenile dementia associated with cortical blindness (Heidenhain's syndrome). J Neurol Neurosurg Psychiatry 1954;17:129-33.

91. Kropp S, Schulz-Schaeffer WJ, Finkenstaedt M, et al. The Heidenhain variant of Creutzfeldt-Jakob disease. Arch Neurol 1999;56:55-61.

92. Motomura S, Yamashita Y, Kawanami S, Ohta M, Kuroiwa Y. An autopsy report of spongiform encephalopathy with Kuru plaque and leukomalacia. Rinsho Shinkeigaku - Clin Neurol 1977;17:758-64.

93. Park TS, Kleinman GM, Richardson EP. Creutzfeldt-Jakob disease with extensive degeneration of white matter. Acta Neuropathol (Berlin) 1980;52:239-42.

94. Mizutani T, Okumura A, Oda M, Shiraki H. Panencephalopathic type of Creutzfeldt-Jakob disease: primary involvement of the cerebral white matter. J Neurol Neurosurg Psychiatry 1981;44:103-15.

95. Kitagawa Y, Gotoh F, Koto A, et al. Creutzfeldt-Jakob disease: a case with extensive white matter degeneration and optic atrophy. J Neurol 1983;229:97-101.

96. Macchi G, Abbamondi AL, Di Trapani G, Sbriccoli A. On the white matter lesions of the Creutzfeldt-Jakob disease. Can a new subentity be recognized in man? J Neurol Sci 1984;63:197-206.

97. Cruz-Sanchez F, Lafuente J, Gertz HJ, Stoltenburg-Didinger G. Spongiform encephalopathy with extensive involvement of white matter. J Neurol Sci 1987;82:81-7.

98. Okiyama R, Tsuchiya K, Furukawa T, Tsukagoshi H, Kosaka K. An autopsy case of panencephalopathic type of Creutzfeldt-Jakob disease: an early clinical sign documented by magnetic resonance imaging. Rinsho Shinkeigaku - Clin Neurol 1989;29:1048-51.

99. Berciano J, Berciano MT, Polo JM, Figols J, Ciudad J, Lafarga M. Creutzfeldt-Jakob disease with severe involvement of cerebral white matter and cerebellum. Virchows Arch A Pathol Anat Histopathol 1990;417:533-8.

100. Krüger H, Meesmann C, Rohrbach E, Müller J, Mertens HG. Panencephalopathic type of Creutzfeldt-Jakob disease with primary extensive involvement of white matter. Eur Neurol 1990;30:115-9.

101. Uchino A, Yoshinaga M, Shiokawa O, Hata H, Ohno M. Serial MR imaging in Creutzfeldt-Jakob disease. Neuroradiology 1991; 33:364-7.

102. Brownell B, Oppenheimer DR. An ataxic form of subacute presenile polioencephalopathy (Creutzfeldt-Jakob disease). J Neurol Neurosurg Psychiatry 1965;28:350-61.

103. Jellinger $K$, Heiss $W$-D, Deisenhammer E. The ataxic (cerebellar) form of Creutzfeldt-Jakob disease. J Neurol 1974;207:289-305.

104. Gomori AJ, Partnow MJ, Horoupian DS, Hirano A. The ataxic form of Creutzfeldt-Jakob disease. Arch Neurol 1973;29:318-23.

105. Jones HR, Hedley-White ET, Freidberg SR, Baker RA. Ataxic Creutzfeldt-Jakob disease: diagnostic techniques and neuropathologic observations in early disease. Neurology 1985;35:254-7.

106. Will RG, Ironside JW, Zeidler M, et al. A new variant of Creutzfeldt-Jakob disease in the UK. Lancet 1996;347:921-5.

107. Chazot G, Broussolle E, Lapras CI, Blättler T, Aguzzi A, Kopp N. New variant of Creutzfeldt-Jakob disease in a 26-year-old French man. Lancet 1996;347:1181.

108. Will RG, Matthews WB. A retrospective study of Creutzfeldt-Jakob disease in England and Wales 1970-79. I. Clinical features. J Neurol Neurosurg Psychiatry 1984;47:134-40. 
109. Maertens P, Quindlen EA. Clinical manifestations. In: Bastian FO, editor. Creutzfeldt-Jakob disease and other transmissible spongiform encephalopathies. St Louis: Mosby-Year Book, 1991:131-52.

110. McNaughton HK, Will RG. Creutzfeldt-Jakob disease presenting acutely as stroke: an analysis of 30 cases. Neurol Infect Epidemiol 1996;2:19-24.

111. Hudson AJ. Amyotrophic lateral sclerosis and its association with dementia, Parkinsonism and other neurological disorders: a review. Brain 1981;104:217-47.

112. Antoine JC, Laplanche JL, Mosnier JF, Beaudry P, Chatelain J, Michel D. Demyelinating peripheral neuropathy with Creutzfeldt-Jakob disease and mutation at codon 200 of the prion protein gene. Neurology 1996;46:1123-7.

113. Esiri MM, Gordon WI, Collinge J, Patten JS. Peripheral neuropathy in Creutzfeldt-Jakob disease. Neurology 1997:48:784.

114. Collinge J, Owen F, Poulter M, et al. Prion dementia without characteristic pathology. Lancet 1990;336:7-9.

115. Packer RJ, Cornblath DR, Gonatas NK, Bruno LA, Asbury AK. Creutzfeldt-Jakob disease in a 20 -year-old woman. Neurology 1980;30:492-6.

116. Monreal J, Collins GH, Masters CL, et al. Creutzfeldt-Jakob disease in an adolescent. J Neurol Sci 1981;52:341-50.

117. Gálvez S, Dörr-Zegers O, Cartier L. Zur Klinik, Neuropathologie und Pathogenese der Creutzfeldt-Jakobschen Krankheit anhand von 40 gesicherten Fällen. Nervenarzt 1982;53:132-40.

118. Raverdy P, Hauw JJ, Cathala F, et al. Maladie de Creutzfeldt-Jakob ayant évolué 34 mois chez une femme de 26 ans. Rev Neurol (Paris) 1983;139:381-3.

119. Brown P, Cathala F, Labauge R, Pages M, Alary JC, Baron $\mathrm{H}$. Epidemiologic implications of Creutzfeldt-Jakob disease in a 19-year-old girl. Eur J Epidemiol 1985;1:42-7.

120. Kulczycki J, Jedrzejowska H, Gajkowski K, TarnowskaDziduszko E, Lojkowska W. Creutzfeldt-Jakob disease in young people. Eur J Epidemiol 1991;7:501-4.

121. Bateman D, Hilton D, Love S, Zeidler M, Beck J, Collinge J. Sporadic Creutzfeldt-Jakob disease in an 18-year-old in the UK. Lancet 1995;346:1155-6.

122. Britton TC, Al-Sarraj S, Shaw C, Campbell T, Collinge J. Sporadic Creutzfeldt-Jakob disease in a 16-year-old in the UK. Lancet 1995;346:1155.

123. Ironside JW, Sutherland K, Bell JE, et al. A new variant of Creutzfeldt-Jakob disease: neuropathological and clinical features. Cold Spring Harbor Symp Quant Biol 1996;61:523-30.

124. Will RG, Stewart G, Zeidler M, MacLeod MA, Knight RSG. Psychiatric features of new variant Creutzfeldt-Jakob disease. Psychol Bull 1999;23:264-7.

125. Zeidler M, Stewart GE, Barraclough CR, et al. New variant Creutzfeldt-Jakob disease: neurological features and diagnostic tests. Lancet 1997;350:903-7.

126.Zeidler M, Johnstone EC, Bamber RWK, et al. New variant Creutzfeldt-Jakob disease: psychiatric features. Lancet 1997;350:908-10.

127. Sellar RJ, Will W, Zeidler M. Imaging of new variant Creutzfeldt disease: the pulvinar sign. Neuroradiology 1997;39(Suppl):S53.

128. Zeidler M, Sellar RJ, Collie DA, et al. The pulvinar sign on magnetic resonance imaging in variant Creutzfeldt-Jakob disease. Lancet 2000;355:1412-8.

129. Wells GAH, Scott AC, Johnson CT, et al. A novel progressive spongiform encephalopathy in cattle. Vet Rec 1987;121:419-20.

130. Alperovitch A, Brown P, Weber T, Pocchiari M, Hofman A, Will R. Incidence of Creutzfeldt-Jakob disease in Europe in 1993. Lancet 1994;343:918.

131. Wilesmith JW, Ryan JBM, Atkinson MJ. Bovine spongiform encephalopathy: epidemiological studies on the origin. Vet Rec 1991;128:199-203.
132. Anderson RM, Donnelly CA, Ferguson NM, et al. Transmission dynamics and epidemiology of BSE in British cattle. Nature 1996;382:779-88.

133. Sawcer SJ, Yuill GM, Esmonde TFG, et al. Creutzfeldt-Jakob disease in an individual occupationally exposed to BSE. Lancet 1993;341:642.

134. Davies PTG, Jahfar S, Ferguson IT, Windl O. Creutzfeldt-Jakob disease in an individual occupationally exposed to BSE. Lancet 1993;342:680.

135. Smith PEM, Zeidler M, Ironside JW, Estibeiro P, Moss TH. Creutzfeldt-Jakob disease in a dairy farmer. Lancet 1995;346:898.

136. Young GR, Fletcher NA, Zeidler M, Estibeiro KL, Ironside JW. Creutzfeldt-Jakob disease in a beef farmer. Lancet 1996;348:610-1

137. Gore SM. More than happenstance: Creutzfeldt-Jakob disease in farmers and young adults. BMJ 1995;511:1416-8.

138. Hill F, Will PG, Ironside J, Collinge J. Type of prion protein in UK farmers with Creutzfeldt-Jakob disease. Lancet 1997;350:188

139. Bruce ME, Will RG, Ironside JW, et al. Transmissions to mice indicate that 'new variant' CJD is caused by the BSE agent. Nature 1997;389:498-501.

140. Ironside JW, Knight RSG, Will RG, Smith PG, Cousens SN. New variant Creutzfeldt-Jakob disease is more common in Britain than elsewhere. BMJ 1998;317:352.

141. Lasmézas CI, Deslys J-P, Demaimay R, Adjou KT, Lamoury F, Dormont D. BSE transmission to macaques. Nature 1996;381:743-4.

142. Hill AF, Debruslais M, Joiner S, et al. The same prion strain causes vCJD and BSE. Nature 1997;389:448-50.

143. Almond J, Pattison J. Human BSE. Nature 1997;389:437-8.

144. Bruce ME, Will RG, Ironside JW, Fraser H. Comparison of the biological characteristics of BSE and CJD in mice. In: Iqbal K, Swaab DF, Winblad B, Wisniewski $\mathrm{H}$, editors. Alzheimer's disease and related disorders. London: Wiley, 1999:553-60.

145. Zeidler M, Stewart G, Cousens SN, Estibeiro K, Will RG. Codon 129 genotype and new variant CJD. Lancet 1997;350:668

146. Cousens SN, Linsell L, Smith PG, et al. Geographical distribution of variant CJD in the UK (excluding Northern Ireland). Lancet 1999;353:18-21.

147. Cousens SN, Vynnycky E, Zeidler M, Will RG, Smith PG. Predicting the CJD epidemic in humans. Nature 1997;385:197-8.

148. Dealler SF. Predictions of the incidence of new variant Creutzfeldt-Jakob disease. Rev Med Microbiol 1998;9:129-34.

149. Ghani AC, Ferguson NM, Donnelly CA, Hagenaars TJ, Anderson RM. Epidemiological determinants of the pattern and magnitude of the vCJD epidemic in Great Britain. Proc R Soc Lond B 1998;265:2443-52.

150. Thomas P, Newby M. Estimating the size of the outbreak of new-variant CJD. Br Food J 1999;101:44-58.

151. Will RG, Cousens SN, Farrington CP, Smith PG, Knight RSG, Ironside JW. Deaths from variant Creutzfeldt-Jakob disease. Lancet 1999;353:979.

152. Anon. Tragedy of variant Creutzfeldt-Jakob disease [editorial]. Lancet 1999;353:939.

153. Gerstmann J, Sträussler E, Scheinker I. Über eine eigenartige hereditär-familiäre Erkrankung des Zentralnervensystems. Zugleich ein Beitrag zur Frage des vorzeitigen lokalen Alterns. Z Ges Neurol Psych 1936;154:736-62.

154. Hsaio K, Prusiner SB. Inherited human prion diseases. Neurology 1990;40:1820-7.

155. Hainfellner JA, Brantner-Inthaler S, Cervenáková L, et al. The original Gerstmann-Straüssler-Scheinker family of Austria: divergent clinicopathological phenotypes but constant PrP genotype. Brain Pathol 1995;5:201-11. 
156. Doh-ura K, Tateishi J, Kitamoto T, Sasaki H, Sakaki Y. Creutzfeldt-Jakob disease patients with congophilic kuru plaques have the missense variant prion protein common to Gerstmann-Sträussler syndrome. Ann Neurol 1990;27:121-6.

157. Warter JM, Steinmetz G, Heldt N, et al. Démence pré-sénile familiale: syndrome de Gerstmann-Sträussler-Scheinker. Rev Neurol (Paris) 1982;138:107-21.

158. Nochlin D, Sumi SM, Bird TD, et al. Familial dementia with PrP-positive amyloid plaques: a variant of Gerstmann-Sträussler syndrome. Neurology 1989;39:910-8.

159. Hsaio KK, Cass C, Schellenberg GD, et al. A prion protein variant in a family with the telencephalic form of Gerstmann-Sträussler-Scheinker syndrome. Neurology 1991;41:681-4.

160. Farlow MR, Yee RD, Dlouhy SR, Conneally PM, Azzarelli B, Ghetti B. Gerstmann-Sträussler-Scheinker disease. I. Extending the clinical spectrum. Neurology 1989;39:1446-52.

161. Ghetti B, Tagliavini F, Masters CL, et al. Gerstmann-Sträussler-Scheinker disease. II. Neurofibrillary tangles and plaques with PrP-amyloid coexist in an affected family. Neurology 1989;39:1453-61.

162. Lugaresi E, Medori R, Montagna $P$, et al. Fatal familial insomnia and dysautonomia with selective degeneration of thalamic nuclei. N Engl J Med 1986;315:997-1003.

163. Medori R, Tritschler HJ, LeBlanc A, et al. Fatal familial insomnia, a prion disease with a mutation at codon 178 of the prion protein gene. N Engl J Med 1992;326:444-9.

164. Manetto V, Medori R, Cortelli P, et al. Fatal familial insomnia: clinical and pathologic study of five new cases. Neurology 1992;42:312-9.

165. Petersen RB, Tabaton M, Berg L, et al. Analysis of the prion protein gene in thalamic dementia. Neurology 1992;42:1859-63.

166. Goldfarb LG, Petersen RB, Tabaton M, et al. Fatal familial insomnia and familial Creutzfeldt-Jakob disease: disease phenotype determined by a DNA polymorphism. Science 1992;258:806-8.

167. Gambetti P, Petersen R, Monari L, et al. Fatal familial insomnia and the widening spectrum of prion diseases. Br Med Bull 1993;49:980-94.

168. Nagayama M, Shinohara Y, Furukawa H, Kitamoto T. Fatal familial insomnia with a mutation at codon 178 of the prion protein gene: first report from Japan. Neurology 1996;47:1313-6.

169. Gambetti P, Parchi P. Insomnia in prion diseases: sporadic and familial. N Engl J Med 1999;340:1675-7.

170. Campbell TA, Palmer MS, Will RG, Gibb WRG, Luthert PJ, Collinge J. A prion disease with a novel 96-base pair insertional mutation in the prion protein gene. Neurology 1996;46:761-6.

171. Mastrianni JA, Nixon R, Layzer R, et al. Prion protein conformation in a patient with sporadic fatal insomnia. N Engl J Med 1999;340:1630-8.

172. Zerr I, Giese A, Windl O, et al. Phenotypic variability in fatal familial insomnia (D178N-129M) genotype. Neurology 1998;51:1398-405.

173. Gajdusek DC, Zigas V. Degenerative disease of the central nervous system in New Guinea: the endemic occurrence of 'kuru' in the native population. N Engl J Med 1957;257:974-8.

174. Glasse R. Cannibalism in the Kuru region of New Guinea. Trans NY Acad Sci 1967;29:748-54.

175. Gajdusek DC. Unconventional viruses and the origin and disappearance of Kuru. Science 1977;197:943-60.

176. Liberski PP, Gajdusek DC. Kuru: forty years later. A historical note. Brain Pathol 1997;7:555-60.

177. Will RG. Surveillance of prion diseases in humans. In: Baker HF, Ridley RM, editors. Methods in molecular medicine: prion diseases. Totowa, NJ: Humana Press, 1996:119-37.
178. Hsaio K, Meiner Z, Kahana E, et al. Mutation of the prion protein in Libyan Jews with Creutzfeldt-Jakob disease. N Engl J Med 1991;324:1091-7.

179. Chapman J, Ben-Israel J, Goldhammer Y, Korczyn AD. The risk of developing Creutzfeldt-Jakob disease in subjects with the PRNP gene codon 200 point mutation. Neurology 1994;44:1683-6.

180. Spudich S, Mastrianni JA, Wrensch M, et al. Complete penetrance of Creutzfeldt-Jakob disease in Libyan Jews carrying the E200K mutation in the prion protein gene. Mol Med 1995;1:607-13.

181. Sparkes RS, Simon M, Cohn VH, et al. Assignment of the human and mouse prion protein genes to homologous chromosomes. Proc Natl Acad Sci USA 1986;83:7358-62.

182. Owen F, Poulter M, Lofthouse R, et al. Insertion in prion protein gene in familial Creutzfeldt-Jakob disease. Lancet 1989;I:51-2.

183. Goldfarb LG, Brown P, Little BW, et al. A new (two repeat) octapeptide coding insert mutation in Creutzfeldt-Jakob disease. Neurology 1993;43:2392-4.

184. Goldfarb LG, Brown P, McCombie WR, et al. Transmissible familial Creutzfeldt-Jakob disease associated with five, seven and eight extra octapeptide coding repeats in the PRNP gene. Proc Natl Acad Sci USA 1991;88:10926-30.

185. Owen F, Poutler M, Shah T, et al. An in-frame insertion in the prion protein gene in familial Creutzfeldt-Jakob disease. Brain Res Mol Brain Res 1990;7:273-6.

186. Poulter M, Baker HF, Frith CD, et al. Inherited prion disease with 144 base pair gene insertion. 1. Genealogical and molecular studies. Brain 1992;115:675-85.

187. Collinge J, Brown J, Hardy J, et al. Inherited prion disease with 144 base pair gene insertion. 2. Clinical and pathological features. Brain 1992;115:687-710.

188. Nicholl D, Windl O, De Silva R, et al. Inherited Creutzfeldt-Jakob disease in a British family associated with a novel 144 base pair insertion of the prion protein gene. J Neurol Neurosurg Psychiatry 1995;58:65-9.

189. Oda T, Kitamoto T, Tateishi J, et al. Prion disease with 144 base pair insertion in a Japanese family line. Acta Neuropathol 1995;90:80-6.

190. Cochran EJ, Bennett DA, Cervenáková L et al. Familial Creutzfeldt-Jakob disease with a five-repeat octapeptide insert mutation. Neurology 1996;47:727-33.

191. Brown P, Goldfarb LG, McCombie WR, et al. Atypical Creutzfeldt-Jakob disease in an American family with an insert mutation in the PRNP amyloid precursor gene. Neurology 1992;42:422-7.

192. Van Gool WA, Hansels GW, Hoogerwaard EM, Wiezer JHA, Wesseling P, Bolhuis PA. Hypokinesia and presenile dementia in a Dutch family with a novel insertion in the prion protein gene. Brain 1995;118:1565-71.

193. Owen F, Poulter M, Collinge J, et al. A dementing illness associated with a novel insertion in the prion protein gene. Brain Res Mol Brain Res 1992;13:155-7.

194. Duchen LW, Poulter M, Harding AE. Dementia associated with a 216 base pair insertion in the prion protein gene: clinical and neuropathological features. Brain 1993;116:555-67.

195. Brown P. The phenotypic expression of different mutations in transmissible human spongiform encephalopathy. Rev Neurol (Paris) 1992;148:317-27.

196. Goldfarb LG, Brown P, Cervenakova L, Gajdusek DC. Molecular genetic studies of Creutzfeldt-Jakob disease. Mol Neurobiol 1994;8:89-97.

197. Doh-ura K, Tateishi J, Sasaki H, Kitamoto T, Sakaki Y. Pro $\rightarrow$ Leu change at position 102 of prion protein is the most common but not the sole mutation related to Gerstmann-Sträussler syndrome. Biochem Biophys Res Commun 1989;163:974-9. 
198. Hsaio K, Baker HF, Crow TJ, et al. Linkage of a prion protein missense variant to Gerstmann-Sträussler syndrome. Nature 1989;338:342-5.

199. Goldgaber D, Goldfarb LG, Brown P, et al. Mutations in familial Creutzfeldt-Jakob disease and Gerstmann-Sträussler-Scheinker's syndrome. Exp Neurol 1989;106:204-6.

200. Kretzschmar HA, Honold G, Seitelberger F, et al. Prion protein mutation in family first reported by Gerstmann, Sträussler, and Scheinker. Lancet 1991;337:1160.

201. Kretzschmar HA, Kufer P, Riethmüller G, DeArmond S, Prusiner SB, Schiffer D. Prion protein mutation at codon 102 in an Italian family with Gerstmann-Sträussler-Scheinker syndrome. Neurology 1992;42:809-10.

202. Miyazono M, Kitamoto T, Doh-ura K, Iwaki T, Tateishi J. Creutzfeldt-Jakob disease with codon 129 polymorphism (valine): a comparative study of patients with codon 102 point mutation or without mutations. Acta Neuropathol 1992;84:349-54.

203. Goldhammer Y, Gabizon R, Meiner Z, Sadeh M. An Israeli family with Gerstmann-Sträussler-Scheinker disease manifesting the codon 102 mutation in the prion protein gene. Neurology 1993;43:2718-9.

204. Laplanche J-L, Delasnerie-Lauprêtre N, Brandel JP, et al. Molecular genetics of prion diseases in France. Neurology 1994;44:2347-51.

205. Furukawa H, Kitamoto T, Tanaka Y, Tateishi J. New variant prion protein in a Japanese family with

Gerstmann-Sträussler syndrome. Brain Res Mol Brain Res 1995;30:385-8.

206. Young $K$, Jones CK, Piccardo $P$, et al. Gerstmann-Sträussler-Scheinker disease with mutation at codon 102 and methionine at codon 129 of PRNP in previously unreported patients. Neurology 1995;45:1127-34.

207. Barbanti P, Fabbrini G, Salvatore M, et al. Polymorphism at codon 129 or codon 219 of PRNP and clinical heterogeneity in a previously unreported family with Gerstmann-Sträussler-Scheinker disease (PrP-P102L mutation). Neurology 1996;47:734-41.

208. Piccardo P, Dlouhy S, Lievens PMJ, et al. Phenotypic variability of Gerstmann-Sträussler-Scheinker disease is associated with prion protein heterogeneity. J Neuropathol Exp Neurol 1998;57:979-88.

209. Kitamoto T, Amano N, Terao Y, et al. A new inherited prion disease (PrP-P105L mutation) showing spastic paraparesis. Ann Neurol 1993;34:808-13.

210. Kitamoto T, Ohta M, Doh-ura K, Hitoshi S, Terao Y, Tateishi J. Novel missense variants of prion protein in Creutzfeldt-Jakob disease or Gerstmann-Sträussler syndrome. Biochem Biophys Res Commun 1993;191:709-14.

211. Yamada $M$, Itoh $Y$, Fujigasaki $H$, et al. A missense mutation at codon 105 with codon 129 polymorphism of the prion protein gene in a new variant of Gerstmann-Sträussler-Scheinker disease. Neurology 1993;43:2723-4.

212. Tateishi J, Kitamoto T, Doh-ura K, et al. Immunochemical, molecular genetic, and transmission studies on a case of Gerstmann-Sträussler-Scheinker syndrome. Neurology 1990;40:1578-81.

213. Tranchant C, Doh-ura K, Warter JM, et al. Gerstmann-Sträussler-Scheinker disease in an Alsatian family: clinical and genetic studies. J Neurol Neurosurg Psychiatry 1992;55:185-7.

214. Kitamoto T, Iizuka R, Tateishi J. An amber mutation of prion protein in Gerstmann-Sträussler syndrome with mutant PrP plaques. Biochem Biophys Res Commun 1993;192:525-31

215. Samaia HB, de Jesus Mari J, Vallada HP, Moura RP, Simpson AJG, Brentani RR. A prion-linked psychiatric disorder. Nature 1997;390:241.
216. Fink JK, Warren JT, Drury I, Murman D, Peacock ML. Allele-specific sequencing confirms novel prion gene polymorphism in Creutzfeldt-Jakob disease. Neurology 1991;41:1647-50.

217. Goldfarb LG, Haltia M, Brown P, et al. New mutation in scrapie amyloid precursor gene (at codon 178) in Finnish Creutzfeldt-Jakob disease kindred. Lancet 1991;337:425.

218. Nieto A, Goldfarb LG, Brown P, et al. Codon 178 mutation in ethnically diverse Creutzfeldt-Jakob disease families. Lancet 1991;337:622-3.

219. Bosque PJ, Vnencak-Jones CL, Johnson MD, Whitlock JA, McLean MJ. A PrP gene codon 178 base substitution and a 24-bp interstitial deletion in familial Creutzfeldt-Jakob disease. Neurology 1992;42:1864-70.

220. Brown P, Goldfarb LG, Kovanen J, et al. Phenotypic characteristics of familial Creutzfeldt-Jakob disease associated with the codon 178Asn PRNP mutation. Ann Neurol 1992;31:282-5.

221. Goldfarb LG, Brown P, Haltia M, et al. Creutzfeldt-Jakob disease cosegregates with the codon 178Asn PRNP mutation in families of European origin. Ann Neurol 1992;31:274-81.

222. Petersen RB, Goldfarb L, Tabaton M, et al. Fatal familial insomnia and one subtype of familial Creutzfeldt-Jakob disease: effect of a polymorphism in the prion protein gene on pathogenic mutation. Neurology 1993;43(Suppl):A192.

223. Hitoshi S, Nagura H, Yamanouchi H, Kitamoto T. Double mutations at codon 180 and codon 232 of the PRNP gene in an apparently sporadic case of Creutzfeldt-Jakob disease. J Neurol Sci 1993;120:208-12.

224. Nitrini R, Rosemberg S, Passos-Bueno MR, et al. Familial spongiform encephalopathy associated with a novel prion protein gene mutation. Ann Neurol 1997;42:138-46.

225. Dlouhy SR, Hsaio K, Farlow MR, et al. Linkage of the Indiana kindred of Gerstmann-Sträussler-Scheinker disease to the prion protein gene. Nature Genet 1992;1:64-7.

226. Hsaio K, Dlouhy SR, Farlow MR, et al. Mutant prion proteins in Gerstmann-Sträussler-Scheinker disease with neurofibrillary tangles. Nature Genet 1992;1:68-71.

227. Goldfarb LG, Mitrová E, Brown P, Toh BH, Gajdusek DC. Mutation of codon 200 of scrapie amyloid protein gene in two clusters of Creutzfeldt-Jakob disease in Slovakia. Lancet 1990;336:514-5.

228. Goldfarb LG, Korczyn AD, Brown P, Chapman J, Gajdusek DC. Mutation in codon 200 of scrapie amyloid precursor gene linked to Creutzfeldt-Jakob disease in Sephardic Jews of Libyan and non-Libyan origin. Lancet 1990;336:637-8.

229. Goldfarb LG, Brown P, Goldgaber D, et al. Identical mutation in unrelated patients with Creutzfeldt-Jakob disease. Lancet 1990;336:174-5.

230. Korczyn AD, Chapman J, Goldfarb LG, Brown P, Gajdusek DC. A mutation in the prion protein gene in Creutzfeldt-Jakob disease in Jewish patients of Libyan, Greek and Tunisian origin. Ann NY Acad Sci 1991;640:171-6.

231. Bertoni JM, Brown P, Goldfarb LG, Rubenstein R, Gajdusek DC. Familial Creutzfeldt-Jakob disease (codon 200 mutation) with supranuclear palsy. JAMA 1992;268:2413-5.

232. Brown P, Gálvez S, Goldfarb LG, et al. Familial Creutzfeldt-Jakob disease in Chile is associated with the codon 200 mutation of the PRNP amyloid precursor gene on chromosome 20. J Neurol Sci 1992;112:65-7.

233. Chapman J, Brown P, Goldfarb LG, Arlazoroff A, Gajdusek DC, Korczyn AD. Clinical heterogeneity and unusual presentations of Creutzfeldt-Jakob disease in Jewish patients with the PRNP codon 200 mutation. J Neurol Neurosurg Psychiatry 1993;56:1109-12.

234. Collinge J, Palmer MS, Campbell T, Sidle KCL, Carroll D, Harding A. Inherited prion disease (PrP lysine 200) in Britain: two case reports. BMJ 1993;306:301-2. 
235. Ripoll L, Laplanche J-L, Salzmann M, et al. A new point mutation in the prion protein gene at codon 210 in Creutzfeldt-Jakob disease. Neurology 1993;43:1934-8.

236. Inoue I, Kitamoto T, Doh-ura K, Shii H, Goto I, Tateishi J. Japanese family with Creutzfeldt-Jakob disease with codon 200 point mutation of the prion protein gene. Neurology 1994;44:299-301.

237. Chapman J, Arlazoroff A, Goldfarb LG, et al. Fatal insomnia in a case of familial Creutzfeldt-Jakob disease with the codon 200Lys mutation. Neurology 1996;46:758-61.

238. Miyakawa $T$, Inoue $K$, Iseki $E$, et al. Japanese Creutzfeldt-Jakob disease patients exhibiting high incidence of the E200K PRNP mutation and located in the basin of a river. Neurol Res 1998;20:684-8.

239. Mastrianni JA, Iannicola C, Myers RM, DeArmond S, Prusiner SB. Mutation of the prion protein gene at codon 208 in familial Creutzfeldt-Jakob disease. Neurology 1996;47:1305-12.

240. Pocchiari M, Salvatore M, Cutruzzolá F, et al. A new point mutation of the prion protein gene in Creutzfeldt-Jakob disease. Ann Neurol 1993;34:802-7.

241. Shimizu T, Tanaka K, Tanahashi N, Fukuuchi Y, Kitamoto T. Creutzfeldt-Jakob disease with a point mutation at codon 232 of prion protein: a case report. Rinsho Shinkeigaku Clin Neurol 1994;24:590-2.

242. Itoh $Y$, Amano T, Shimizu T, Hashimoto J, Kubo A, Fukuuchi $Y$. Single-photon emission computed tomography image of benzodiazepine receptors in a patient with Creutzfeldt-Jakob disease. Int Med 1998;37:896-900.

243. Rosenmann H, Halimi M, Kahana I, Biran I, Gabizon R. Differential allelic expression of PrP mRNA in carriers of the E200K mutation. Neurology 1997;49:851-6.

244. Vnencak-Jones CL, Phillips JA. Identification of heterogeneous PrP gene deletions in controls by detection of allele-specific heteroduplexes (DASH). Am J Hum Genet 1992;50:871-2.

245. Prusiner SB, Scott MR. Genetics of prions. Annu Rev Genet 1997;31:139-75.

246. Kimberlin RH. Transmissible encephalopathies in animals. Can J Vet Res 1990;54:30-7.

247. Bruce M, Chree A, McConnell I, Foster J, Pearson G, Fraser $H$. Transmission of bovine spongiform encephalopathy and scrapie to mice: strain variation and the species barrier. Phil Trans R Soc Lond B 1994;343:405-11.

248. Bruce ME. Scrapie strain variation and mutation. Br Med Bull 1993;49:822-38.

249. Collinge J, Sidle KCL, Meads J, Ironside J, Hill AF. Molecular analysis of prion strain variation and the aetiology of 'new variant' CJD. Nature 1996;383:685-90.

250. Parchi P, Castellani R, Capellari S, et al. Molecular basis of phenotypic variability in sporadic Creutzfeldt-Jakob disease. Ann Neurol 1996;39:767-78.

251. Deslys J-P, Lasmézas C, Dormont D. Selection of specific strains in iatrogenic Creutzfeldt-Jakob disease. Lancet 1994;343:848-9.

252. Brown P, Preece MA, Will RG. 'Friendly fire' in medicine: hormones, homografts, and Creutzfeldt-Jakob disease. Lancet 1992;340:24-7.

253. Esmonde T, Lueck CJ, Symon L, Duchen LW, Will RG. Creutzfeldt-Jakob disease and lyophilised dura mater grafts: report of two cases. J Neurol Neurosurg Psychiatry 1993;56:999-1000.

254. Kimberlin RH, Walker CA. Pathogenesis of experimental scrapie. CIBA Found Symp 1988;1135:37-62.

255. Kimberlin RH, Walker CA. Pathogenesis of scrapie in mice after intragastric infection. Virus Res 1989;12:213-20.

256. Hadlow WJ, Kennedy RC, Race RE. Natural infection of Suffolk sheep with scrapie virus. J Infect Dis 1982;146:657-64.
257. Alperovitch A, Zerr I, Pocchiari M, et al. Codon 129 prion protein genotype and sporadic Creutzfeldt-Jakob disease. Lancet 1999;353:1673-4.

258. De Silva R, Ironside JW, McCardle L, et al. Neuropathological phenotype and 'prion protein' genotype correlation in sporadic Creutzfeldt-Jakob disease. Neurosci Lett 1994;179:50-2.

259. Doh-ura K, Kitamoto T, Sakaki Y, Tateishi J. CJD discrepancy. Nature 1991;353:801-2.

260. Tranchant C, Geranton L, Guiraud-Chaumeil C, Mohr M, Warter JM. Basis of phenotypic variability in sporadic Creutzfeldt-Jakob disease. Neurology 1999;52:1244-9.

261. Baker HF, Poulter M, Crow TJ, et al. Aminoacid polymorphism in human prion protein and age at death in inherited prion disease. Lancet 1991;337:1286.

262. Brown P, Cervenáková L, Goldfarb LG, et al. Iatrogenic Creutzfeldt-Jakob disease: an example of the interplay between ancient genes and modern medicine. Neurology 1994;44:291-3.

263. Heckmann JG, Lang CJG, Petruch F, et al. Transmission of Creutzfeldt-Jakob disease via a corneal transplant. J Neurol Neurosurg Psychiatry 1997;63:388-90.

264. Lang CJG, Heckmann JG, Neundörfer B. Creutzfeldt-Jakob disease via dural and corneal transplants. J Neurol Sci 1998;160:128-39.

265. Martínez-Lage JF, Poza M, Sola J, et al. Accidental transmission of Creutzfeldt-Jakob disease by dural cadaveric grafts. J Neurol Neurosurg Psychiatry 1994;57:1091-4.

266. Yamada S, Aiba T, Endo Y, Hara M, Kitamoto T, Tateishi J. Creutzfeldt-Jakob disease transmitted by a cadaveric dura mater graft. Neurosurgery 1994;34:740-4.

267. Yamada M, Itoh $Y$, Suematsu N, Matsushita M, Otomo E. Panencephalopathic type of Creutzfeldt-Jakob disease associated with cadaveric dura mater graft. J Neurol Neurosurg Psychiatry 1997;63:524-7.

268. Antoine JC, Michel D, Bertholon P, et al. Creutzfeldt-Jakob disease after extracranial dura mater embolization for a nasopharyngeal angiofibroma. Neurology 1997;48:1451-3.

269. Pocchiari M, Masullo C, Salvatore M, Genuardi M, Galgani S. Creutzfeldt-Jakob disease after commercial dura mater graft. Lancet 1992;340:614-5.

270. Goldfarb LG, Brown P, Goldgaber D, et al. Patients with Creutzfeldt-Jakob disease and kuru lack the mutation in the PRIP gene found in Gerstmann-Sträussler syndrome, but they show a different double-allele mutation in the same gene. Am J Hum Genet 1989;45(Suppl):A189.

271. Collinge J, Palmer MS, Dryden AJ. Genetic predisposition to iatrogenic Creutzfeldt-Jakob disease. Lancet 1991;337:1441-2.

272. Labauge $P$, Pagès $M$, Blard J-M, Chatelain J, Laplanche J-L. Valine homozygous $129 \mathrm{PrP}$ genotype in a French growthhormone-related Creutzfeldt-Jakob disease patient. Neurology 1993;43:447.

273. Billette de Villemeur T, Gelot T, Deslys JP, et al. Iatrogenic Creutzfeldt-Jakob disease in three growth hormone recipients: a neuropathological study. Neuropathol Appl Neurobiol 1994;20:111-7.

274. Masson C, Delalande I, Deslys JP, et al. Creutzfeldt-Jakob disease after pituitary-derived human growth hormone therapy: two cases with valine 129 homozygous genotype. Neurology 1994;44:179-80.

275. Deslys JP, Jaegly A, d'Aignaux JH, Mouthon F, Billette de Villemeur T, Dormont D. Genotype at codon 129 and susceptibility to Creutzfeldt-Jakob disease. Lancet 1998;351:1251.

276. Dickinson AG. Scrapie in sheep and goats. Front Biol 1976;44:209-41. 
277. Kimberlin RH, Cole S, Walker CA. Temporary and permanent modification to a single strain of mouse scrapie on transmission to rats and hamsters. J Gen Virol 1987;68:1875-81.

278. Kimberlin RH, Walker CA, Fraser H. The genomic identity of different strains of mouse scrapie is expressed in hamsters and preserved on reisolation in mice. J Gen Virol 1989;70:2017-25.

279. Telling GC, Scott M, Mastrianni J, et al. Prion propagation in mice expressing human and chimeric PrP transgenes implicates the interaction of cellular PrP with another protein. Cell 1995;83:79-90.

280. Collins S, Law MG, Fletcher A, Boyd A, Kaldor J, Masters CL. Surgical treatment and risk of sporadic Creutzfeldt-Jakob disease: a case-control study. Lancet 1999;353:693-7.

281. Will RG, Kimberlin RH. Creutzfeldt-Jakob disease and the risk from blood or blood products. Vox Sang 1998;75:178-80.

282. Elliott V. CJD fear prompts rule on contact lens fitting. The London Times, 24 June 1999. London.

283. Gaytan-Garcia S, Gilbert JJ, Kaufmann JCE. Jakob-Creutzfeldt disease associated with Wernicke encephalopathy. Can J Neurol Sci 1988;15:156-60.

284. Smith SJM, Kocen RS. A Creutzfeldt-Jakob like syndrome due to lithium toxicity. J Neurol Neurosurg Psychiatry 1988;51:120-3.

285. Kemperman CJF, Notermans SLH. Creutzfeldt-Jakob like syndrome due to lithium toxicity. J Neurol Neurosurg Psychiatry 1989;52:291.

286. Pietrini W. Creutzfeldt-Jakob disease presenting as Wernicke-Korsakoff syndrome. J Neurol Sci 1992;108:149-53.

287. Seipelt M, Zerr I, Nau R, et al. Hashimoto's encephalitis as a differential diagnosis of Creutzfeldt-Jakob disease. J Neurol Neurosurg Psychiatry 1999;66:172-6.

288. Ironside JW. Neuropathological diagnosis of human prion disease: morphological studies. In: Baker HF, Ridley RM, editors. Methods in molecular medicine: prion diseases. Totowa, NJ: Humana Press, 1996:35-57.

289. Hogan RN, Brown P, Heck E, Cavanagh HD. Risk of prion disease transmission from ocular donor tissue transplantation. Cornea 1999;18:2-11.

290. Blisard KS, Davis LE, Harrington MG, Lovell JK, Kornfield M, Berger ML. Pre-mortem diagnosis of Creutzfeldt-Jakob disease by detection of abnormal cerebrospinal fluid proteins. J Neurol Sci 1990;99:75-81.

291. Whittle IR, Will RG, Ironside JW. Brain biopsy and patients with atypical presentations of sporadic Creutzfeldt-Jakob disease. J Neurol Neurosurg Psychiatry 1997;63:547-8.

292. Castellani R, Parchi P, Stahl J, Capellari S, Cohen M, Gambetti P. Early pathologic and biochemical changes in Creutzfeldt-Jakob disease: study of brain biopsies. Neurology 1996;46:1690-3.

293. Poursines Y, Boudouresques J, Roger J. Processus dégénératif atrophique diffus, à prédominance thalamostriée. Séméiologie extra-pyramidale et psychique variable. Évolution subaiguë à terminaison démentielle. Rev Neurol (Paris) 1953;89:266-71.

294. Abbott J. The EEC in Jakob-Creutzfeldt's disease. EEG Clin Neurophysiol 1959;11:184-5.

295. Butler HM, Williams GH, McCormack LJ. Clinical observations on seven pathologically proved cases of Creutzfeldt-Jakob disease. Trans Am Neurol Assoc 1963;88:30-2.

296. Nelson JR, Leffman $\mathrm{H}$. The human diffusely projecting system: evoked potentials and interactions. Arch Neurol 1963;8:544-56.

297. Small JG, Bleisch VR, Woolsey RM. Subacute spongiform encephalopathy: comment on the literature and case report. EEG Clin Neurophysiol 1964;17:451-72.
298. Lafon R, Labauge R, van Bogaert L, Castan P. Sur l'unité histopathologique des encéphalopathies subaiguës (types Creutzfeldt-Jakob, Heidenhain et Nevin). Rev Neurol (Paris) 1965;112:201-27.

299. Nevin S. On some aspects of cerebral degeneration in later life. Proc R Soc Lond B 1967;60:517-26.

300. Gloor P, Kalabay O, Giard N. The electroencephalogram in diffuse encephalopathies: electroencephalographic correlates of grey and white matter lesions. Brain 1968;91:779-802.

301. Hauser-Dumur F, Radvanyi MF. Évolution électroencéphalographique de deux cas de syndrome de Creutzfeldt-Jakob tardifs. Rev Neurol (Paris) 1969;121:241-4.

302. Goldhammer Y, Bubis JJ, Sarova-Pinhas I, Braham J. Subacute spongiform encephalopathy and its relation to Jakob-Creutzfeldt disease: report on six cases. J Neurol Neurosurg Psychiatry 1972;35:1-10.

303. Lee RG, Blair RDG. Evolution of EEG and visual evoked response changes in Creutzfeldt-Jakob disease. EEG Clin Neurophysiol 1973;35:133-42.

304. Ott TH, Despland PA. Sur l'évolution électro-clinique d'une spongiose cérébrale. Schweiz Arch Neurol Neurochir Psychiatr 1975;116:93-106.

305. Goto K, Umezaki H, Suetsugu M. Electroencephalographic and clinicopathological studies on Creutzfeldt-Jakob syndrome. J Neurol Neurosurg Psychiatry 1976;39:931-40.

306. Szirmai I, Guseo A, Czopf J, Pálffy G. Analysis of clinical and electrophysiological findings in Jakob-Creutzfeldt disease. Arch Psychol Nervenk 1976;222:315-23.

307. Paty J, Bonnaud E, Latinville D, et al. Corrélations électrophysiologiques, cliniques et anatomiques dans un cas de maladie de Creutzfeldt-Jakob (forme de Heidenhain). Rev Neurol (Paris) 1978;134:223-31.

308. Torres F, Hutton JT. Clinical neurophysiology of dementia Neurol Clin 1986;4:369-86.

309. Court L, Bert J. Electrophysiologie des encéphalopathies transmissibles. Path Biol 1995;43:25-42.

310. Budka H, Aguzzi A, Brown P, et al. Tissue handling in suspected Creutzfeldt-Jakob disease (CJD) and other human spongiform encephalopathies (prion diseases). Brain Pathol 1995;5:319-22.

311. Chiofalo N, Fuentes A, Gálvez S. Serial EEG findings in 27 cases of Creutzfeldt-Jakob disease. Arch Neurol 1980;37:143-5.

312. Levy SR, Chiappa KH, Burke CJ, Young RR. Early evolution and incidence of electroencephalographic abnormalities in Creutzfeldt-Jakob disease. J Clin Neurophysiol 1986;3:1-21.

313. Bortone E, Bettoni L, Giorgi C, Terzano MG, Trabattoni GR, Mancia D. Reliability of EEG in the diagnosis of Creutzfeldt-Jakob disease. EEG Clin Neurophysiol 1994;90:323-30.

314. Steinhoff BJ, Räcker S, Herrendorf G, et al. Accuracy and reliability of periodic sharp wave complexes in Creutzfeldt-Jakob disease. Arch Neurol 1996;53:162-6.

315. Burger LJ, Rowan AJ, Goldensohn ES. Creutzfeldt-Jakob disease. An electroencephalographic study. Arch Neurol 1972;26:428-33.

316. Elliott F, Gardner-Thorpe C, Barwick DD, Foster JB. Jakob-Creutzfeldt disease: modification of clinical and electroencephalographic activity with methylphenidate and diazepam. J Neurol Neurosurg Psychiatry 1974;37:879-87.

317. Aguglia U, Farnarier G, Tinuper P, Rey M, Gomez M, Quattrone A. Subacute spongiform encephalopathy with periodic paroxysmal activities: clinical evolution and serial EEG findings in 20 cases. Clin Electroencephalogr 1987;18:147-58.

318. Kuritzky A, Davidovitch S, Sandbank U, Bechar M. Normal EEG in Creutzfeldt-Jakob disease. Neurology 1980:30:1134-5. 
319. Zochodne DW, Young GB, McLachlan RS, Gilbert JJ, Vinters HV, Kaufmann JCE. Creutzfeldt-Jakob disease without periodic sharp wave complexes: a clinical, electroencephalographic, and pathologic study. Neurology 1988;38:1056-60.

320. Tietjen GE, Drury I. Familial Creutzfeldt-Jakob disease without periodic EEG activity. Ann Neurol 1990;28:585-8.

321. Donnet A, Farnarier G, Gambarelli D, Aguglia U, Regis H. Sleep electroencephalogram at the early stage of Creutzfeldt-Jakob disease. Clin Electroencephalogr 1992;23:118-25.

322. Aguglia U, Oliveri RL, Gambardella A, Zappia M, Quattrone A. Combined neurophysiological studies in Creutzfeldt-Jakob disease: a case report. Clin Electroencephalogr 1989;20:103-10.

323. Urbach H, Klisch J, Wolf HK, Brechtelsbauer D, Gass S, Solymosi L. MRI in sporadic Creutzfeldt-Jakob disease: correlation with clinical and neuropathological data. Neuroradiology 1998;40:65-70.

324. Lee KE, Loh NK, Tan AK, Tija HT. Creutzfeldt-Jakob disease presenting with visual blurring, diplopia and visual loss: Heidenhain's variant. Ann Acad Med Singapore 1998;27:854-6.

325. Jibiki I, Fukushima T, Kobayashi K, Aoki T, Yamaguchi N. Antagonizing correlation between periodic synchronous discharges and photically induced giant evoked responses in Creutzfeldt-Jakob disease (Heidenhain type): a case study. Psych Clin Neurosci 1995;49:87-90.

326. Aoki T, Kobayashi K, Jibiki I, et al. An autopsied case of Creutzfeldt-Jakob disease with the lateral geniculate body lesion showing antagonizing correlation between periodic synchronous discharges and photically induced giant evoked responses. Psych Clin Neurosci 1998;52:333-7.

327. Capon A, Colin F, Deltenre P, Hubert JP, Flament-Durand J. Etude électrophysiologique de deux cas de maladie de Creutzfeldt-Jakob. Rev EEG Neurophysiol Clin 1976;6:130-6.

328. Adam J, Crow TJ, Duchen LW, Scaravilli F, Spokes E. Familial cerebral amyloidosis and spongiform encephalopathy. J Neurol Neurosurg Psychiatry 1982;45:37-45.

329. Wolpow ER, Richardson EP. Case records of the Massachusetts General Hospital. Case 45-1980. N Engl J Med 1980;303:1162-71.

330. Tintner R, Brown P, Hedley-White ET, Rappaport EB, Piccardo CP, Gajdusek DC. Neuropathologic verification of Creutzfeldt-Jakob disease in the exhumed American recipient of human pituitary growth hormone: epidemiologic and pathogenetic implications. Neurology 1986;36:932-6.

331. Tsutsui J, Kawashima S, Kajikawa I, Shirabe T, Terao A. Electrophysiological and pathological studies on Creutzfeldt-Jakob disease with retinal involvement. Doc Ophthalmol 1986;63:13-21.

332. Aguglia U, Farnarier G, Regis H, Oliveri RL, Quattrone A. Sensory evoked potentials in Creutzfeldt-Jakob disease. Eur Neurol 1990;30:157-61.

333. Aguglia U, Gambarelli D, Farnarier G, Quattrone A. Different susceptibilities of the geniculate and extrageniculate visual pathways to human Creutzfeldt-Jakob disease (a combined neurophysiologicalneuropathological study). EEG Clin Neurophysiol 1991;78:413-23.

334. Fukui R, Tobimatsu S, Kato M. Periodic synchronous discharges and visual evoked potentials in Creutzfeldt-Jakob disease: PSD-triggered flash VEPs. EEG Clin Neurophysiol 1994;90:433-7.

335. de Seze J, Hache JC, Vermersch P, et al. Creutzfeldt-Jakob disease: neurophysiologic visual impairments. Neurology 1998;51:962-7.
336. Neetens A, Martin JJ. Neuro-ophthalmological aspects of prion diseases. Neuro-ophthalmology 1998;19:137-44.

337. Aguglia U, Oliveri RL, Gambardella A, Quattrone A. Functional integrity of benzodiazepine receptors of the geniculo-striate visual pathways in Creutzfeldt-Jakob disease. J Neurol 1993;240:25-7.

338. Powell-Jackson J, Weller RO, Kennedy P, Preece MA, Whitcombe EM, Newsom-Davis J. Creutzfeldt-Jakob disease after administration of human growth hormone. Lancet 1985;II:244-6.

339. Signorino M, Giovagnoli AR, Sirrocchi G, Censori B. Unusual findings in Creutzfeldt-Jakob disease: case report. Ital J Neurol Sci 1988;9:279-82.

340. Ehrenberg B, Munsat T, Sharetts S, Adelman L. Evoked potentials in Creutzfeldt-Jakob disease. Early diagnosis? EEG Clin Neurophysiol 1984;57:3P.

341. Richard P, Renault F, Ostré C, Auzoux-Chevé M. Neurophysiological follow-up in two children with Creutzfeldt-Jakob disease after human growth hormone treatment. EEG Clin Neurophysiol 1994;91:100-7.

342. Renault F, Richard P. Early electroretinogram alterations in Creutzfeldt-Jakob disease after growth hormone treatment. Lancet 1991;339:191.

343. Billette de Villemeur T, Beauvais P, Gourmelen M, Richardet JM. Creutzfeldt-Jakob disease in children treated with growth hormone. Lancet 1991;337:864-5.

344. Billette de Villemeur T, Deslys J-P, Pradel A, et al. Creutzfeldt-Jakob disease from contaminated growth hormone extracts in France. Neurology 1996;47:690-5.

345. Lesser RL, Albert DM, Bobowick AR, O'Brien FH. Creutzfeldt-Jakob disease and optic atrophy. Am J Ophthalmol 1979;87:317-21.

346. Sato Y, Chiba S, Miyagishi T. A case of panencephalopathic type of Creutzfeldt-Jakob disease with retinal involvement. Hokkaido Igaku Zasshi - Hokkaido J Med Sci 1992;67:703-11.

347. Hogan RN, Kingsbury DT, Baringer JR, Prusiner SB. Retinal degeneration in experimental Creutzfeldt-Jakob disease. Lab Invest 1983;49:708-15.

348. Browne TR, Richardson EP. Case records of the Massachusetts General Hospital. Case 43-1977. N Engl J Med 1977;297:930-7.

349. Rao CVGK, Brennan TG, Garcia JH. Computed tomography in the diagnosis of Creutzfeldt-Jacob disease. J Comput Assist Tomogr 1977;1:211-5.

350. Rice GPA, Paty DW, Ball MJ, Tatham R, Kertesz A. Spongiform encephalopathy of long duration: a family study. Can J Neurol Sci 1980;7:171-6.

351. Zieger A, Vonofakos D, Gräfin Vitzthum H. Creutzfeldt-Jakobsche Krankheit: Das Computertomogramm in Korrelation zu klinischen, elektroenzephalographischen und neuropathologischen Befunden. Nervenarzt 1981;52:685-91.

352. Khurana RK, Garcia JH. Autonomic dysfunction in subacute spongiform encephalpathy. Arch Neurol 1981;38:114-7.

353. Kashiwamura K, Takasato C, Kodama K, Kusunose $Y$, Sakata Y. Serial computed tomographic study on subacute spongiform encephalopathy. Clin Neurol 1981;21:938-43.

354. Schneck SA, Hedley-White ET. Case records of the Massachusetts General Hospital. Case 49-1983. N Engl J Med 1983;309:1440-9.

355. Friedland RP, Prusiner SB, Jagust WJ, Budinger TF, Davis RL. Bitemporal hypometabolism in Creutzfeldt-Jakob disease measured by positron emission tomography with $\left[{ }^{18} \mathrm{~F}\right]$-2-fluorodeoxyglucose. J Comput Assist Tomogr 1984;8:978-8.1.

356. Gálvez S, Cartier L. Computed tomography findings in 15 cases of Creutzfeldt-Jakob disease with histological verification. J Neurol Neurosurg Psychiatry 1984;47:1244-6. 
357. Westphal KP, Schachenmayr W. Computed tomography during Creutzfeldt-Jakob disease. Neuroradiology 1985;27:362-4.

358. Kovanen J, Erkinjuntti T, Iivanainen M, et al. Cerebral MR and CT imaging in Creutzfeldt-Jakob disease. J Comput Assist Tomogr 1985;9:125-8.

359. LeMay M. CT changes in dementing diseases: a review. Am J Neuroradiol 1986;7:841-53.

360. Chan YW, Ho HC, Kay CS, Ip YM. Creutzfeldt-Jakob disease in Hong Kong: a case report. J Neurol Sci 1987;80:143-52.

361. Kazukawa S, Nakamura I, Endo M, Hori A, Inao G. Serial polysomnograms in Creutzfeldt-Jakob disease. Jpn J Psychiatry Neurol 1987;41:651-61.

362. Gertz H-J, Henkes H, Cervos-Navarro J. Creutzfeldt-Jakob disease: correlation of MRI and neuropathologic findings. Neurology 1988;38:1481-2.

363. Schlenska GK, Walter GF. Serial computed tomographic findings in Creutzfeldt-Jakob disease. Neuroradiology 1989;31:303-6.

364. Pearl GS, Anderson RE. Creutzfeldt-Jakob disease: high caudate signal on magnetic resonance imaging. South Med J 1989;82:1177-80.

365. Cochius JI, Mack K, Burns RJ, Alderman CP, Blumbergs PC. Creutzfeldt-Jakob disease in a recipient of human pituitaryderived gonadotrophin. Aust NZ J Med 1990;20:592-3.

366. Holthoff VA, Sandmann J, Pawlik G, Schröder R, Heiss WD. Positron emission tomography in Creutzfeldt-Jakob disease. Arch Neurol 1990;47:1035-8.

367. Shishido F, Uemura K, Inugami A, et al. Brain glucose metabolism in a patient with Creutzfeldt-Jakob disease measured by positron emission tomography. Kaku Igaku Japan J Nucl Med 1990;27:649-54.

368. Miyashita $\mathrm{K}$, Inuzuka $\mathrm{T}$, Kondo $\mathrm{H}$, et al. Creutzfeldt-Jakob disease in a patient with a cadaveric dural graft. Neurology 1991;41:940-1.

369. Milton WJ, Atlas SW, Lavi E, Mollman JE. Magnetic resonance imaging of Creutzfeldt-Jakob disease. Ann Neurol 1991;29:438-40.

370. Falcone S, Quencer RM, Bowen B, Bruce JH, Naidich TP. Creutzfeldt-Jakob disease: focal symmetrical cortical involvement demonstrated by MR imaging. Am J Neuroradiol 1992;13:403-6.

371. Hayashi R, Hanyu N, Kuwabara T, Moriyama S. Serial computed tomographic and electroencephalographic studies in Creutzfeldt-Jakob disease. Acta Neurol Scand 1992;85:161-5.

372. Kohira I, Ishuzu $H$, Shohmori $T$, et al. Diffuse reduced uptake in ${ }^{99 \mathrm{~m}} \mathrm{Tc}-\mathrm{HM}$-PAO SPECT and high level of neuronspecific enolase in cerebrospinal fluid in the early stage of Creutzfeldt-Jakob disease [in Japanese]. No to Shinkei Brain Nerve 1992;44:579-82.

373. Sato Y, Chiba S, Miyagishi T, Hayasaka K. Serial brain CT and ${ }^{123}$ I-IMP SPECT in a case with Creutzfeldt-Jakob disease. Hokkaido Igaku Zasshi - Hokkaido J Med Sci 1992;67:141-7.

374. Barboriak DP, Provenzale JM, Boyko OB. MR diagnosis of Creutzfeldt-Jakob disease: significance of high signal intensity of the basal ganglia. AJR 1994;162:137-40.

375. Ogawa $\mathrm{T}$, Inugami A, Fujita $\mathrm{H}$, et al. Serial positron emission tomography with ${ }^{18} \mathrm{~F}$-fluorodeoxyglucose in Creutzfeldt-Jakob disease. Am J Neuroradiol 1995;16:978-81.

376. Garciá Santos JM, López Corbalán JA, Martínez-Lage JF, Sicilia Guillén J. CT and MRI in iatrogenic and sporadic Creutzfeldt-Jakob disease: as far as imaging perceives. Neuroradiology 1996;38:226-31.

377. Onofrj M, Fulgente T, Gambi D, Macchi G. Early MRI findings in Creutzfeldt-Jakob disease. J Neurol 1993;240:423-6.
378. Koch TK, Berg BO, De Armond SJ, Gravina RF. Creutzfeldt-Jakob disease in a young adult with idiopathic hypopituitarism: possible relation to the administration of cadaveric human growth hormone. N Engl J Med 1985;313:731-3.

379. Berciano J, Díez C, Polo JM, Pascual J, Figols J. CT appearance of panencephalopathic and ataxic type of Creutzfeldt-Jakob disease. J Comput Assist Tomogr 1991;15:332-4.

380. Kawata A, Suga M, Oda M, Hayashi H, Tanabe H. Creutzfeldt-Jakob disease with congophilic Kuru plaques: $\mathrm{CT}$ and pathological findings of the cerebral white matter. J Neurol Neurosurg Psychiatry 1992;55:849-51.

381. Berciano J, Pascual J, Polo JM, Combarros O, Figols J, Diez C. Ataxic type of Creutzfeldt-Jakob disease with disproportionate enlargement of the fourth ventricle: a serial CT study. J Neurol Neurosurg Psychiatry 1997;62:295-7.

382. Esmonde TFG, Will RG. Magnetic resonance imaging in Creutzfeldt-Jakob disease. Ann Neurol 1992;31:230-1.

383. Röther J, Schwartz A, Härle M, Wentz KU, Berlit P, Hennerici M. Magnetic resonance imaging follow-up in Creutzfeldt-Jakob disease. J Neurol 1992;239:404-6.

384. Yamamoto K, Morimatsu M. Increased signal in basal ganglia and white matter on magnetic resonance imaging in Creutzfeldt-Jakob disease. Ann Neurol 1992;32:114.

385. Di Rocco A, Molinari S, Stollman AL, Decker A, Yahr MD. MRI abnormalities in Creutzfeldt-Jakob disease. Neuroradiology 1993;35:584-5.

386. Tartaro A, Fulgente T, Delli Pizzi C, Bonomo L, Bocola V, Onofrj M. MRI alterations as an early finding in Creutzfeld-Jakob disease. Eur J Radiol 1993;17:155-8.

387. Iwasaki Y, Ikeda K, Tagaya N, Kinoshita M. Magnetic resonance imaging and neuropathological findings in two patients with Creutzfeldt-Jakob disease. J Neurol Sci 1994;126:228-31.

388. Heinz A, Schmidt LG, Winterer G, Gerhard L, Przuntek H. Optische und taktile Halluzinose als klinischer Beginn einer Creutzfeldt-Jakob-Erkrankung. Nervenarzt 1995;66:712-6.

389. Kujat C, Hagen T, Feiden W. Creutzfeldt-Jakob-Krankheit. Welche Rolle spielt die MR-Tomographie? Radiologe 1995;35:834-7.

390. Finkenstaedt M, Szudra A, Zerr I, et al. MR imaging of Creutzfeldt-Jakob disease. Radiology 1996;199:793-8.

391. Gold M, Rojiani A, Murtaugh R. A 66-year-old woman with a rapidly progressing dementia and basal ganglia involvement. J Neuroimaging 1997;7:171-5.

392. Yoon SS, Chan S, Chin S, Lee K, Goodman RR. MRI of Creutzfeldt-Jakob disease: asymmetric high signal intensity of the basal ganglia. Neurology 1995;45:1932-3.

393. Hill AF, Butterworth RJ, Joiner $\mathrm{S}$, et al. Investigation of variant Creutzfeldt-Jakob disease and other human prion diseases with tonsil biopsy samples. Lancet 1999;353:183-9.

394. Falcone S, Quencer RM, Donovan Post MJ. Magnetic resonance imaging of unusual intracranial infections. Top Magn Reson Imaging 1994;6:41-52.

395. Stafen W, Trinka E, Iglseder B, Pilz P, Homann N, Ladurner G. Clinical and diagnostic findings in a patient with Creutzfeldt-Jakob disease (type Heidenhain). J Neuroimaging 1997;7:50-4.

396. Graham GD, Petroff OAC, Blamire AM, Rajkowska G, Goldman-Rakic P, Prichard JW. Proton magnetic resonance spectroscopy in Creutzfeldt-Jakob disease. Neurology 1993:43:2065-8.

397. Shih WJ, Markesbery WR, Clark DB, et al. Iodine- 123 HIPDM brain imaging findings in subacute spongiform encephalopathy (Creutzfeldt-Jakob disease). J Nucl Med 1987;28:1484-7.

398. Cochius JI, Hyman N, Esiri MM. Creutzfeldt-Jakob disease in a recipient of human pituitary-derived gonadotrophin: a second case. J Neurol Neurosurg Psychiatry 1992;55:1094-5. 
399. Kirk A, Ang LC. Unilateral Creutzfeldt-Jakob disease presenting as rapidly progressive aphasia. Can J Neurol Sci 1994;21:350-2.

400. Jibiki I, Fukushima T, Kobayashi K, et al. Utility of ${ }^{123} \mathrm{I}-\mathrm{IMP}$ SPECT brain scans for the early detection of site-specific abnormalities in Creutzfeldt-Jakob disease (Heidenhain type): a case study. Neuropsychobiology 1994;29:117-9.

401. Zeidler M, Will RG, Ironside JW, Sellar R, Wardlaw J. Magnetic resonance imaging is not a sensitive test for Creutzfeldt-Jakob disease. BMJ 1996;312:844.

402. Defebvre L, Destée A, Caron J, Ruchoux MM, Wurtz A, Remy J. Creutzfeldt-Jakob disease after an embolization of intercostal arteries with cadaveric dura mater suggesting a systemic transmission of the prion agent. Neurology 1997;48:1470-1.

403. Schwaninger M, Winter R, Hacke W, et al. Magnetic resonance imaging in Creutzfeldt-Jakob disease: evidence of focal involvement of the cortex. J Neurol Neurosurg Psychiatry 1997;63:408-9.

404. Bahn MM, Kido DK, Lin W, Pearlman AL. Brain magnetic resonance diffusion abnormalities in Creutzfeldt-Jakob disease. Arch Neurol 1997;54:1411-5.

405. Demaerel P, Baert AL, Vanopdenbosch L, Robberecht W, Dom R. Diffusion-weighted magnetic resonance imaging in Creutzfeldt-Jakob disease. Lancet 1997;349:847-8.

406. Bahn MM, Parchi P. Abnormal diffusion-weighted magnetic resonance images in Creutzfeldt-Jakob disease. Arch Neurol 1999;56:577-83.

407. Yee AS, Simon JH, Anderson CA, Sze C-I, Filley CM. Diffusion-weighted MRI of right-hemisphere dysfunction in Creutzfeldt-Jakob disease. Neurology 1999;52:1514.

408. Cohen D, Krausz Y, Lossos A, Ben-David E, Atlan H. Brain SPECT imaging with Tc-99m-PAO in Creutzfeldt-Jakob disease. Clin Nucl Med 1989;14:808-10.

409. Marcus HS, Duchen LW, Parkin EM, et al. Creutzfeldt-Jakob disease in recipients of human growth hormone in the United Kingdom: a clinical and radiographic study. Q J Med 1992;82:43-51.

410. Heye N, Farahati J, Heinz A, Büttner T, Przuntek H, Reiners C. Topodiagnostik der Creutzfeldt-Jakobschen Krankheit durch HMPAO-SPECT. Nukl Med 1993;32:57-9.

411. Victoroff J, Ross GW, Benson DF, Verity MA, Vinters HV. Posterior cortical atrophy: neuropathologic correlations. Arch Neurol 1994;51:269-74.

412. Aharon-Peretz J, Peretz A, Hemli JA, Honigman S, Israel O. SPECT diagnosis of Creutzfeldt-Jakob disease. J Nucl Med 1995;36:616-7.

413. Grünwald F, Pohl C, Bender $\mathrm{H}$, et al. ${ }^{18} \mathrm{~F}-$ fluorodeoxyglucose-PET and ${ }^{99} \mathrm{~m}$ Tc-bicisate-SPECT in Creutzfeldt-Jakob disease. Ann Nucl Med 1996;10:131-4.

414. Miller DA, Vitti RA, Maslack MM. The role of ${ }^{99 \mathrm{~m}} \mathrm{Tc}-$ HMPAO SPECT in the diagnosis of Creutzfeldt-Jakob disease. Am J Neuroradiol 1998;19:454-5.

415. de Silva R, Patterson J, Hadley D, Russell A, Turner M, Zeidler M. Single photon emission computed tomography in the identification of new variant Creutzfeldt-Jakob disease: case reports. BMJ 1998;316:593-4.

416. Gorman DG, Benson DF, Vogel DG, Vinters HV. Creutzfeldt-Jakob disease in a pathologist. Neurology 1992;42:463.

417. Goldman S, Liard A, Flament-Durand J, et al. Positron emission tomography and histopathology in Creutzfeldt-Jakob disease. Neurology 1993;43:1828-30

418. Goto I, Taniwaki T, Hosokawa S, Otsuka M, Ichiya T, Ichimiya A. Positron emission tomographic (PET) studies in dementia. J Neurol Sci 1993;114:1-6.

419. Perani $D$, Cortelli $P$, Lucignani $G$, et al. $\left[{ }^{18} \mathrm{~F}\right] \mathrm{FDG}$ PET in fatal familial insomnia: the functional effects of thalamic lesions. Neurology 1993;43:2565-9.

420. Fisher CM. The clinical picture in Creutzfeldt-Jakob disease. Trans Am Neurol Assoc 1960;85:147-50.
421. Christensen E, Brun A. Subacute spongiform encephalopathy: spongiform cerebral atrophy. Neurology 1963;13:455-63.

422. Wakayama Y, Shibuya S, Kawase J, Sagawa F, Hashizume Y. High neuron-specific enolase level of cerebrospinal fluid in the early stage of Creutzfeldt-Jakob disease. Klin Wochenschr 1987;65:798-801.

423. Jimi T, Wakayama $Y$, Shibuya $S$, et al. High levels of nervous system-specific proteins in cerebrospinal fluid in patients with early stage Creutzfeldt-Jakob disease. Clin Chim Acta 1992;211:37-46.

424. Zerr I, Bodemer M, Räcker S, et al. Cerebrospinal fluid concentration of neuron-specific enolase in diagnosis of Creutzfeldt-Jakob disease. Lancet 1995;345:1609-10.

425. Zerr I, Bodemer M, Otto M, et al. Diagnosis of Creutzfeldt-Jakob disease by two-dimensional gel electrophoresis of cerebrospinal fluid. Lancet 1996;348:846-9.

426. Manaka H, Kato T, Kurita K, et al. Marked increase in cerebrospinal fluid ubiquitin in Creutzfeldt-Jakob disease. Neurosci Lett 1992;139:47-9.

427. Awerbuch G, Peterson P, Sandyk R. Elevated cerebrospinal fluid lactic acid levels in Creutzfeldt-Jakob disease. Int J Neurosci 1988;42:1-5.

428. Otto M, Wiltfang J, Tumani $\mathrm{H}$, et al. Elevated levels of tauprotein in cerebrospinal fluid of patients with Creutzfeldt-Jakob disease. Neurosci Lett 1997;225:210-2.

429. Otto M, Stein H, Szudra A, et al. S-100 protein concentration in the cerebrospinal fluid of patients with Creutzfeldt-Jakob disease. J Neurol 1997;244:566-70.

430. Otto M, Wiltfang J, Kretzschmar HA, et al. Diagnosis of Creutzfeldt-Jakob disease by measurement of S100 protein in serum: prospective case-control study. BMJ 1998;316:577-82.

431. Pocchiari M. Early identification of variant Creutzfeldt-Jakob disease. BMJ 1998;316:563-4.

432. Heizmann CW. Subtypes of S100 proteins must be identified. BMJ 1999;318:538.

433. Sharief MK, Green A, Dick JPR, Gawler J, Thompson EJ. Heightened intrathecal release of proinflammatory cytokines in Creutzfeldt-Jakob disease. Neurology 1999;52:1289-91.

434. Harrington MG, Merril CR, Asher DM, Gajdusek DC. Abnormal proteins in the cerebrospinal fluid of patients with Creutzfeldt-Jakob disease. N Engl J Med 1986;315:279-83.

435. Zerr I, Bodemer M, Weber T. The 14-3-3 brain protein and transmissible spongiform encephalopathy. N Engl J Med 1997;336:874

436. Zerr I, Bodemer M, Gefeller O, et al. Detection of 14-3-3 protein in the cerebrospinal fluid supports the diagnosis of Creutzfeldt-Jakob disease. Ann Neurol 1998;43:32-40.

437. Rosenmann H, Meiner Z, Kahana E, et al. Detection of 14-3-3 protein in the CSF of genetic Creutzfeldt-Jakob disease. Neurology 1997;49:593-5.

438. Hsich G, Kenney K, Gibbs CJ, Lee KH, Harrington MG. The 14-3-3 brain protein in cerebrospinal fluid as a marker for transmissible spongiform encephalopathies. N Engl J Med 1996;335:924-30.

439. Brecher K, Stopa EG, Kenney K. Concurrent herpes simplex virus encephalitis and Creutzfeldt-Jakob disease. J Neurol Neurosurg Psychiatry 1998;64:418-9.

440. Moussavian M, Potolicchio S, Jones R. The 14-3-3 brain protein and transmissible spongiform encephalopathy. N Engl J Med 1997;336:873-4.

441. Morrison D. 14-3-3: modulators or signalling proteins? Science 1994;266:56-7.

442. Roos R, Gajdusek DC, Gibbs CJ. Liver disease in Creutzfeldt-Jakob disease (subacute spongiform encephalopathy). Neurology 1971;21:397-8. 
443. Tanaka M, Iizuka O, Tatsuhiko Y. Hepatic dysfunction in Creutzfeldt-Jakob disease. Neurology 1992;42:1249.

444. Tanaka M, Tanaka K, Miyatake T. Lymphocytes in Creutzfeldt-Jakob disease. Neurology 1993;43:2155-6.

445. Iwasaki Y, Kinoshita M. Liver in Creutzfeldt-Jakob disease. Neurology 1993;43:457.

446. Leblhuber F, Walli J, Tilz GP, Jellinger K, Wachter H, Fuchs D. Increased serum neopterin concentrations in a patient with Creutzfeldt-Jakob disease. J Neurol Neurosurg Psychiatry 1996;61:211-2.

447. Meiner Z, Halimi M, Polakiewicz RD, Prusiner SB, Gabizon $R$. Presence of prion protein in peripheral tissues of Libyan Jews with Creutzfeldt-Jakob disease. Neurology 1992;42:1355-60.

448. Schreuder BE, van Keulen LJ, Vromans ME, Langeveld JP, Smits MA. Tonsillar biopsy and $\mathrm{PrP}^{\mathrm{Sc}}$ detection in the preclinical diagnosis of scrapie. Vet Rec 1998;142:564-8.

449. Hill AF, Zeidler M, Ironside J, Collinge J. Diagnosis of new variant Creutzfeldt-Jakob disease by tonsil biopsy. Lancet 1997;349:99-100.

450. Kawashima T, Furukawa H, Doh-ura K, Iwaki T. Diagnosis of new variant Creutzfeldt-Jakob disease by tonsil biopsy. Lancet 1997;350:68-9.

451. Collinge J, Rossor MN, Thomas D, Frosh A, Tolley N. Tonsil biopsy helps diagnose new variant Creutzfeldt-Jakob disease. BMJ 1998;317:472.

452. Zeidler M, Knight R, Stewart G, et al. Routine tonsil biopsy for diagnosis of new variant Creutzfeldt-Jakob disease is not justified. BMJ 1999;318:538.

453. O’Rourke KL, Baszler TV, Parish SM, Knowles DP. Preclinical detection of $\mathrm{PrP}^{\mathrm{Sc}}$ in nictitating membrane lymphoid tissue of sheep. Vet Rec 1996;142:489-91.

454. Hilton DA, Fathers E, Edwards P, Ironside JW, Zaijcek J. Prion immunoreactivity in appendix before clinical onset of variant Creutzfeldt-Jakob disease. Lancet 1998;352:703-4.

455. Bernoulli C, Siegfried J, Baumgartner G, et al. Danger of accidental person-to-person transmission of Creutzfeldt-Jakob disease by surgery. Lancet 1977;I:478-9.

456. Gibbs CJ, Asher DM, Kobrine A, Amyx HL, Sulima MP, Gajdusek DC. Transmission of Creutzfeldt-Jakob disease to a chimpanzee by electrodes contaminated during neurosurgery. J Neurol Neurosurg Psychiatry 1994;57:757-8.

457. Foncin JF, Gaches J, Cathala F, El Sherif E, Le Beau J. Transmission iatrogène interhumaine possible de maladie de Creutzfeldt-Jakob avec atteinte des grains du cervelet. Rev Neurol (Paris) 1980;136:280.

458. Will RG, Matthews WB. Evidence for case-to-case transmission of Creutzfeldt-Jakob disease. J Neurol Neurosurg Psychiatry 1982;45:235-8.

459. Nevin S, McMenemey WH, Behrman S, Jones DP. Subacute spongiform encephalopathy: a subacute form of encephalopathy attributable to vascular dysfunction (spongiform cerebral atrophy). Brain 1960;83:519-64.

460. Gaches J, Supino-Viterbo V, Oughourlian JM. Unusual electroencephalographic and clinical evolution of a case of meningioma of the left temporo-occipital convexity. Eur Neurol 1971;5:155-64.

461. Prichard J, Thadani V, Kalb R, Manuelidis E, Hadler J. Rapidly progressive dementia in a patient who received a cadaveric dura mater graft. MMWR 1987;36:49-55.

462. Thadani V, Penar PL, Partington J, et al. Creutzfeldt-Jakob disease probably acquired from a cadaveric dura mater graft: case report. J Neurosurg 1988;69:766-9.

463. Masullo C, Pocchiari M, Macchi G, Alema G, Piazza G, Panzera MA. Transmission of Creutzfeldt-Jakob disease by dural cadaveric graft. J Neurosurg 1989;71:954-5.

464. Nisbet TJ, Donaldson IM, Bishara SN. Update: Creutzfeldt-Jakob disease in a second patient who received a cadaveric dura mater graft. MMWR 1989;38:37-43.
465. Nisbet TJ, MacDonaldson I, Bishara SN. Creutzfeldt-Jakob disease in a second patient who received a cadaveric dura mater graft. JAMA 1989;261:1118.

466. Willison HJ, Gale AN, McLaughlin JE. Creutzfeldt-Jakob disease following cadaveric dura mater graft. J Neurol Neurosurg Psychiatry 1991;54:940.

467. Martínez-Lage JF, Sola J, Poza M, Esteban JA. Pediatric Creutzfeldt-Jakob disease: probable transmission by a dural graft. Childs Nerv Syst 1993;9:239-42.

468. Takayama S, Hatsuda N, Matsumura K, Nakasu S, Handa J. Creutzfeldt-Jakob disease transmitted by cadaveric dural graft: a case report. No Shinkei Geka - Neurol Surg 1993;21:167-70.

469. Lane KL, Brown P, Howell DN, et al. Creutzfeldt-Jakob disease in a pregnant woman with an implanted dura mater graft. Neurosurgery 1994;34:737-40.

470. Clavel M, Clavel P. Creutzfeldt-Jakob disease transmitted by dura mater graft. Eur Neurol 1996;36:239-40.

471. Takashima S, Tateishi J, Taguchi Y, et al. Creutzfeldt-Jakob disease with a widespread presence of kuru-type plaques after cadaveric dural graft replacement: an autopsy case. Rinsho Shinkeigaku - Clin Neurol 1997;37:824-8.

472. Radbauer C, Hainfellner JA, Gaudernak T, Deecke L, Budka H. Creutzfeldt-Jakob-Krankheit bei einem DuraTransplantat-Empfanger: Erstbeobachtung in Österreich. Wien Klin Wochenschr 1998;110:496-500.

473. Sato T, Hoshi K, Yoshino H, Urata J, Nakamura Y, Yanagawa $\mathrm{H}$. Creutzfeldt-Jakob disease associated with dura mater grafts: Japan, January 1979-May 1996. JAMA 1998;279:11-2.

474. Diringer $H$, Braig HR. Infectivity of unconventional viruses in dura mater. Lancet 1989;I:439-40.

475. Tange RA, Troost D, Limburg M. Progressive fatal dementia (Creutzfeldt-Jakob disease) in a patient who received homograft tissue for tympanic membrane closure. Eur Arch Oto-Rhino-Laryngol 1990;247:199-201.

476. Hintz R, MacGillivray M, Joy A, Tintner R. Fatal degenerative neurological disease in patients who received pituitary-derived human growth hormone. MMWR 1985;34:359-66.

477. Gibbs CJ, Joy A, Heffner R, et al. Clinical and pathological features and laboratory confirmation of Creutzfeldt-Jakob disease in a recipient of pituitary-derived human growth hormone. N Engl J Med 1985;313:734-8.

478. Weller RO, Steart PV, Powell-Jackson JD. Pathology of Creutzfeldt-Jakob disease associated with pituitary-derived human growth hormone administration. Neuropathol Appl Neurobiol 1986;12:117-29.

479. Croxson M, Brown P, Synek B, et al. A new case of Creutzfeldt-Jakob disease associated with human growth hormone therapy in New Zealand. Neurology 1988;38:1128-30.

480. Marzewski DJ, Towfighi J, Harrington MG, Merril CR, Brown P. Creutzfeldt-Jakob disease following pituitaryderived human growth hormone therapy: a new American case. Neurology 1988;38:1131-3.

481. Buchanan CR, Preece MA, Milner RDG. Mortality, neoplasia, and Creutzfeldt-Jakob disease in patients treated with human pituitary growth hormone in the United Kingdom. BMJ 1991;302:824-8.

482. Fradkin JE, Schonberger LB, Mills JL, et al. Creutzfeldt-Jakob disease in pituitary growth hormone recipients in the United States. JAMA 1991;265:880-4.

483. Macario ME, Vaisman M, Buescu A, Moura Neto V, Auaujo HMM, Chagas C. Pituitary growth hormone and Creutzfeldt-Jakob disease. BMJ 1991;302:1149.

484. Billette de Villemeur T, Gourmelen M, Beauvais $P$, et al. Maladie de Creutzfeldt-Jakob chez quatre enfants traités par hormone de croissance. Rev Neurol (Paris) 1992;148:328-34. 
485. Ellis CJ, Katifi H, Weller RO. A further British case of growth hormone induced Creutzfeldt-Jakob disease. J Neurol Neurosurg Psychiatry 1992;55:1200-2.

486. Delisle MB, Fabre N, Rochiccioli P, Doerr-Schott J, Rumeau JL, Bes A. Maladie de Creutzfeldt-Jakob après traitement par l'hormone de croissance extractive humaine: étude clinico-pathologique. Rev Neurol (Paris) 1993;149:524-7.

487. New MI, Brown P, Temeck JW, Owens C, Hedley-White ET, Richardson EP. Preclinical Creutzfeldt-Jakob disease discovered at autopsy in a human growth hormone recipient. Neurology 1988;38:1133-4.

488. Preece MA. Creutzfeldt-Jakob disease: implications for growth hormone deficient children. Neuropathol Appl Neurobiol 1986;12:509-15.

489. Brown P. The decline and fall of Creutzfeldt-Jakob disease associated with human growth hormone therapy. Neurology 1988;38:1135-7.

490. Brown P. Human growth hormone therapy and Creutzfeldt-Jakob disease: a drama in three acts. Pediatrics 1988;81:85-92.

491. Brown P. Iatrogenic Creutzfeldt-Jakob disease. Aust NZ J Med 1990;20:633-5.

492. Job JC, Maillard F, Goujard J. Epidemiologic survey of patients treated with growth hormone in France in the period 1959-1990. Horm Res 1992;38(Suppl 1):35-43.

493. Brown P, Gajdusek DC, Gibbs CJ, Asher DM. Potential epidemic of Creutzfeldt-Jakob disease from human growth hormone therapy. N Engl J Med 1985;313:728-31.

494. Perry HM. Risk of Creutzfeldt-Jakob disease in bodybuilders. BMJ 1993;307:803.

495. Verdrager J. New variant Creutzfeldt-Jakob disease and bovine pituitary growth hormone. Lancet 1998;351:112-3.

496. Brown P. Environmental causes of human spongiform encephalopathy. In: Baker HF, Ridley RM, editors. Methods in molecular medicine: prion diseases. Totowa, NJ: Humana Press, 1996:139-54.

497. Manuelidis EE, Kim JH, Mericangas JR, Manuelidis L. Transmission to animals of Creutzfeldt-Jakob disease from human blood. Lancet 1985;II:896-7.

498. Tamai Y, Kojima H, Kitajima R, et al. Demonstration of the transmissible agent in tissue from a pregnant woman with Creutzfeldt-Jakob disease. N Engl J Med 1992;327:649.

499. Manuelidis EE, Gorgacz EJ, Manuelidis L. Viremia in experimental Creutzfeldt-Jakob disease. Science 1978;200:1069-71.

500. Diringer H. Sustained viremia in experimental hamster scrapie. Arch Virol 1984;82;105-9.

501. Brown P. Can Creutzfeldt-Jakob disease be transmitted by transfusion? Curr Opin Hematol 1995;2:472-7.

502. Brown P, Rohwer RG, Dunstan BC, MacAuley C, Gajdusek DC, Drohan WN. The distribution of infectivity in blood components and plasma derivatives in experimental models of transmissible spongiform encephalopathy. Transfusion 1998;38:810-6.

503. Ludlam CA. New-variant Creutzfeldt-Jakob disease and treatment of haemophilia. Lancet 1997;350:1704.

504. Little BW, Mastranni J, DeHaven AL, Brown P, Goldfarb L, Gajdusek DC. The epidemiology of Creutzfeldt-Jakob disease in Eastern Pennsylvania. Neurology 1993;43:A316.

505. Esmonde TFG, Will RG, Slattery JM, et al. Creutzfeldt-Jakob disease and blood transfusion. Lancet 1993;341:205-7.

506. Kondo K, Kuroiwa Y. A case control study of Creutzfeldt-Jakob disease: association with physical injuries. Ann Neurol 1982;11:377-81.

507. Wientjens DPWM, Davanipour Z, Hofman A, et al. Risk factors for Creutzfeldt-Jakob disease: a reanalysis of case-control studies. Neurology 1996;46:1287-91.

508. Van Duijn CM, Delasnerie-Lauprêtre N, Masullo C, et al. Case-control study of risk factors of Creutzfeldt-Jakob disease in Europe during 1993-95. Lancet 1998;351:1081-5.
509. Ricketts MN, Cashman NR, Stratton EE, El Saadany S. Is Creutzfeldt-Jakob disease transmitted in blood? Emerg Infect Dis 1997;3:155-63.

510. Watkins AM. Creutzfeldt-Jakob disease and blood transfusion. BMJ 1991;302:1537.

511. Klein R, Dumble LJ. Transmission of Creutzfeldt-Jakob disease by blood transfusion. Lancet 1993;341:708.

512. Heye N, Hensen S, Müller N. Creutzfeldt-Jakob disease and blood transfusion. Lancet 1994;343:298-9.

513. Créange A, Gray F, Cesaro P, et al. Creutzfeldt-Jakob disease after liver transplantation. Ann Neurol 1995;38:269-72.

514. Riggs JE. Creutzfeldt-Jakob disease in a prolific blood donor. Arch Neurol 1997;54:1323.

515. Patry D, Curry B, Easton D, Mastrianni JA, Hogan DB. Creutzfeldt-Jakob disease (CJD) after blood product transfusion from a donor with CJD. Neurology 1998;50:1872-3.

516. Collins S, Masters CL. Iatrogenic and zoonotic Creutzfeldt-Jakob disease: the Australian perspective. Med J Austral 1996;164:598-602.

517. Herzberg L. Creutzfeldt-Jakob disease and corneal grafts. Med J Austral 1979;1:248.

518. World Health Organization. Report of WHO consultation on medicinal and other products in relation to human and animal transmissible spongiform encephalopathies. Geneva: World Health Organization, 1999.

519. Contreras M, Barbara J. Creutzfeldt-Jakob disease and blood transfusion. BMJ 1991;302:1148-9.

520. Herzberg L, Herzberg BN, Gibbs CJ, Sullivan W, Amyx H, Gajdusek DC. Creutzfeldt-Jakob disease: hypothesis for high incidence in Libyan Jews in Israel. Science 1974;186:848.

521. Alter M. Creutzfeldt-Jakob disease: hypothesis for high incidence in Libyan Jews in Israel. Science 1974;186:848.

522. Alter M, Frank Y, Doyne H, Webster DD. Creutzfeldt-Jakob disease after eating ovine brains? N Engl J Med 1975;292:927.

523. Alter M, Kahana E. Creutzfeldt-Jakob disease among Libyan Jews in Israel. Science 1976;192:428.

524. Alter M, Hoenig E, Pratzon G. Creutzfeldt-Jakob disease: possible association with eating brains. $\mathrm{N}$ Engl J Med 1977;296:820-1.

525. Mitrova E, Mayer V. Inherited susceptibility, ovine brain consumption and Creutzfeldt-Jakob disease (CJD). J Neurol 1981;226:219-20.

526. Kamin M, Patten BM. Creutzfeldt-Jakob disease: possible transmission to humans by consumption of wild animal brains. Am J Med 1984;76:142-5.

527. Berger JR, Waisman E, Weisman B. Creutzfeldt-Jakob disease and eating squirrel brains. Lancet 1997;350:642.

528. Davanipour Z, Alter M, Sobel E, Asher DM, Gajdusek DC. A case-control study of Creutzfeldt-Jakob disease: dietary risk factors. Am J Epidemiol 1985;122:443-51.

529. Hansen M. Creutzfeldt-Jakob disease. N Engl J Med 1999;340:1687-8.

530. Aguzzi A. Neuro-immune connection in spread of prions in the body? Lancet 1997;349:742-3.

531. Collinge J, Hawke S. B lymphocytes in prion neuroinvasion: central or peripheral players? Nature Med 1998;4:1369-70.

532. Alpers M. Epidemiology and clinical aspects of kuru. In: Prusiner SB, McKinley SB, editors. Prions: novel infectious pathogens causing scrapie and Creutzfeldt-Jakob disease. San Diego: Academic Press, 1987:451-65.

533. Brown $\mathrm{P}$, Cervenáková L, McShane L, et al. Creutzfeldt-Jakob disease in a husband and wife. Neurology 1998;50:684-8.

534. Zanusso G, Nardelli E, Rosati A, et al. Simultaneous occurrence of spongiform encephalopathy in a man and his cat in Italy. Lancet 1998;352:1116-7. 
535. Scott JR, Foster JD, Fraser H. Conjunctival instillation of scrapie in mice can produce disease. Vet Microbiol 1993;34:305-9.

536. Fraser JR, Foster JD, Fraser H. Scrapie can be transmitted to mice by instillation of inoculum into the conjunctiva. BMJ 1996;312:181.

537. Marsh RF, Hanson RP. Transmissible mink encephalopathy: infectivity of corneal epithelium. Science 1975;187:656.

538. Manuelidis EE, Angelo JN, Gorgacz EJ, Kim JH, Manuelidis L. Experimental Creutzfeldt-Jakob disease transmitted via the eye with infected cornea. N Engl J Med 1977;296:1334-6.

539. Hogan RN, Bowman KA, Baringer JR, Prusiner SB. Replication of scrapie prions in hamster eyes precedes retinal degeneration. Ophthalmic Res 1986;18:230-5.

540. Tateishi J. Transmission of Creutzfeldt-Jakob disease from human blood and urine into mice. Lancet 1985;II:1074.

541. Fraser H, Dickinson AG. Targeting of scrapie lesions and spread of agent via the retino-tectal projection. Brain Res 1985;346:32-41.

542. Liberski PP, Yanagihara R, Gibbs CJ, Gajdusek DC. Spread of Creutzfeldt-Jakob disease virus along visual pathways after intraocular inoculation. Arch Virol 1990;111:141-7.

543. Scott JR, Fraser H. Enucleation after intraocular scrapie injection delays the spread of infection. Brain Res 1989;504:301-5.

544. Uchiyama S, Ishida C, Yago S, Kurumaya H, Kitamoto T. An autopsy case of Creutzfeldt-Jakob disease associated with corneal transplantation. Dementia 1994;8:466-73.

545. DeVoe AG. Complications of keratoplasty. Am J Ophthalmol 1975;79:907-12.

546. Allan B, Tuft S. Transmission of Creutzfeldt-Jakob disease in corneal grafts. BMJ 1997;315:1553-4.

547. Henderson M. Health alert after the eyes of CJD victim are transplanted. The London Times, 1 December 1997, London.

548. Christie B. Inquiry ordered after organ donor found to have CJD. BMJ 1997;315:1485.

549. Stewart W. Independent review of an eye transplantation/ CJD incident in 1997. London: Royal College of Ophthalmologists, 1998.

550. Morrice GD. CJD was not diagnosed until eight months after organ donor's death. BMJ 1998;316:630.

551. Tullo A. CJD and the eye. Focus 1998;7:1-2.

552. O'Day DM. Diseases potentially transmitted through corneal transplantation. Ophthalmology 1989;96:1133-8.

553. Hogan RN, Cavanagh HD. Transplantation of corneal tissue from donors with diseases of the central nervous system. Cornea 1995;14:547-53.

554. Davanipour Z, Goodman L, Alter M, Sobel E, Asher D, Gajdusek DC. Possible modes of transmission of Creutzfeldt-Jakob disease. N Engl J Med 1984;311:1582-3.

555. Davanipour Z, Alter M, Sobel E, Asher D, Gajdusek DC. Creutzfeldt-Jakob disease: possible medical risk factors. Neurology 1985;35:1483-6.

556. Fross RD. Ophthalmological precautions in Creutzfeldt-Jakob disease. Ann Neurol 1986;20:748.

557. Davanipour Z, Ziogas A, Sobel E, et al. Ocular tonometry and transmissible spongiform encephalopathy. Am J Epidemiol 1998;147 (Suppl):S76.

558. Rizzo M, Corbett JJ, Thompson HS. Is applanation tonometry a risk factor for transmission of Creutzfeldt-Jakob disease? Arch Ophthalmol 1987;105:314.

559. Schoene WC, Masters CL, Gibbs CJ, et al. Transmissible spongiform encephalopathy (Creutzfeldt-Jakob disease): atypical clinical and pathological findings. Arch Neurol 1981;38:473-7.

560. Miller DC. Creutzfeldt-Jakob disease in histopathology technicians. N Engl J Med 1988;318:853-4.

561. Sitwell L, Lach B, Atack E, Atack D, Izukawa D. Creutzfeldt-Jakob disease in histopathology technicians. N Engl J Med 1988;318:854.
562. Berger JR, David NJ. Creutzfeldt-Jakob disease in a physician: a review of the disorder in health care workers. Neurology 1993;43:205-6.

563. Berger JR, David NJ. CJD in health care workers. Neurology 1993;43:2421.

564. Weber T, Tumani H, Holdorff B, et al. Transmission of Creutzfeldt-Jakob disease by handling of dura mater. Lancet 1993;341:123-4.

565. Traub RD, Gadjusek DC, Gibbs CJ. Precautions in conducting biopsies and autopsies on patients with presenile dementia. J Neurosurg 1974;41:394-5.

566. Traub RD, Gajdusek DC, Gibbs CJ. Precautions in autopsies on Creutzfeldt-Jakob disease. Am J Clin Pathol 1975;64:287.

567. Gajdusek DC, Gibbs CJ, Asher DM, et al. Precautions in medical care of, and in handling materials from patients with transmissible virus dementia (Creutzfeldt-Jakob disease). N Engl J Med 1977;297:1253-8.

568. Budka H, Aguzzi A, Brown P, et al. Konsensusbericht: Gewebsbehandlung bei Verdacht auf Creutzfeldt-JakobKrankheit und andere spongiforme Enzephalopathien (Prionen-Krankheiten) des Menschen. Pathologe 1996;17:171-6.

569. Advisory Committee on Dangerous Pathogens Spongiform Encephalopathy Advisory Committee. Transmissible spongiform encephalopathy agents: safe working and the prevention of infection. London: HMSO, 1998.

570. Hernàndez-Palazón J, Martínez-Lage JF, Tortosa JA, GarcíaCayuela JM. Anaesthetic management in patients suspected of, or at risk of, having Creutzfeldt-Jakob disease. Br J Anaesth 1998;80:516-8.

571. Aguzzi A, Collinge J. Post-exposure prophylaxis after accidental prion inoculation. Lancet 1997;350:1519-20.

572. Dealler S. Post-exposure prophylaxis after accidental prion inoculation. Lancet 1998;351:600.

573. Brown P, Rohwer RG, Gajdusek DC. Sodium hydroxide decontamination of Creutzfeldt-Jakob disease virus. N Engl J Med 1984;310:727.

574. Committee on Health Care Issues ANARRN, White CL, Brown $\mathrm{P}$, et al. Precautions in handling tissues, fluids, and other contaminated materials from patients with documented or suspected Creutzfeldt-Jakob disease. Ann Neurol 1986;19:75-7.

575. Rappaport EB. Iatrogenic Creutzfeldt-Jakob disease. Neurology 1987;37:1520-2.

576. Wight A. PL(92)CO/4: Neuro and ophthalmic surgery procedures on patients with or suspected to have, or at risk of developing, Creutzfeldt-Jakob disease (CJD), or Gerstmann-Sträussler-Scheinker syndrome (GSS). J Public Health Med 1993;15:209-10.

577. Metters JS. Neuro and ophthalmic surgery procedures on patients with or suspected to have, or at risk of developing, Creutzfeldt-Jakob disease (CJD), or Gerstmann-Sträussler-Scheinker syndrome (GSS). J Public Health Med 1993;15:210-1.

578. Holmes SJ, Ironside JW, Shalet SM. Neurosurgery in a patient with Creutzfeldt-Jakob disease after pituitary derived growth hormone therapy in childhood. J Neurol Neurosurg Pyschiatry 1996;60:333-5.

579. Dormont D. Creutzfeldt-Jakob disease and transplantation: facts and fables. Transplant Proc 1996;28:2931-3.

580. Eye Bank Association of America. Medical Standards. 8-12. 1994.

581. Austin JH. Precautions in Creutzfeldt-Jakob disease. Ann Neurol 1986;20:748.

582. Zeidler M, Brown P. More patients should be excluded from being tissue donors. BMJ 1998;316:1170-1.

583. SEAC. Summary of spongiform encephalopathy advisory committee meeting on 3 June, 1999. SEAC 1/99. 23 June 1999. 
584. Brown P, Gibbs CJ, Amyx HL, et al. Chemical disinfection of Creutzfeldt-Jakob disease virus. N Engl J Med 1982;306:1279-82.

585. Ernst DR, Race RE. Comparative analysis of scrapie agent inactivation methods. J Virol Methods 1993;41:193-201.

586. Taylor DM, McConnell I. Autoclaving does not decontaminate formol-fixed scrapie tissues. Lancet 1988;I:1463-4.
587. Brown P, Wolff A, Gajdusek DC. A simple and effective method for inactivating virus infectivity in formalin-fixed tissue samples from patients with Creutzfeldt-Jakob disease. Neurology 1990;40:887-90.

588. Manuelidis L. Decontamination of Creutzfeldt-Jakob disease and other transmissible agents. J Neurovirol 1997;3:62-5. 